iSIM: An Integrated Design Method for Commercializing Service Innovation

\author{
Eng K. Chew \\ Faculty of Engineering \& IT, \\ University of Technology, \\ P. O. Box 123 Broadway \\ NSW 2007, Australia \\ Telephone: +61295144504 \\ eng.chew@uts.edu.au
}




\title{
iSIM: An Integrated Design Method for Commercializing Service Innovation
}

\author{
Eng K. Chew
}

Faculty of Engineering \& IT, University of Technology, Sydney, Australia. eng.chew@uts.edu.au

\begin{abstract}
Service innovation is focused on customer value creation. At its core, customer centric service innovation is technology-enabled, human-centered, and process-oriented. To profit from such innovation, firms need an integrated crossdisciplinary, holistic method to design and commercialize service innovation. From diverse but interrelated strands of theories from service science, strategic management, organization science and information systems literatures, this article develops a new integrated design method, known as iSIM (integrated Service Innovation Method), for simultaneous service innovation and business model design for sustained customer value co-creation with the firm. Following design science research method, the article theoretically defines and integrates iSIM's seven constitutive design process-elements: service strategy, customer type / value proposition, service concept, service system, customer experience, service architecture and monetization into a coherent and end-to-end aligned integrated design method. It explains how $i$ SIM would be holistically and iteratively practiced by practitioners, and conceptually exemplifies its utility via telco and Amazon case studies using secondary data. Perspectives on $i$ SIM from selected practitioners are discussed which confirm iSIM's potential utility
\end{abstract}


for their business. Managerial implications of implementing the $i \mathrm{SIM}$ and potential areas for further research are also discussed.

Keywords: service concept; service design; service architecture; customer experience; business model; service innovation

\section{Introduction}

The need for superior business model to profit from technology and service innovation is well known (Baden-Fuller \& Haefliger, 2013; Chesbrough, 2010; Johnson et al, 2008; Osterwalder \& Pigneur, 2005; Zott \& Amit, 2010; Teece, 2010). Service innovation (Chen et al, 2009; Ordanini \& Parasuraman, 2011) and business model innovation (Aspara et al, 2010; Amit \& Zott, 2012; Chesbrough, 2010; Doz \& Kosonen, 2010) are both closely linked to business strategy and have also been shown to enhance firm performance. In the emergent digital business world, it becomes relatively easy for entrepreneurs to disrupt established firms' business models by innovating new valuable services (e.g. Netflix versus Blockbuster) that consumers want and are willing to pay for. Service innovation by these entrepreneurs is achieved through commercialization of creative design of information technologies into attractive products or platforms (Yeo et al, 2010; Tiwana et al, 2010) offering innovative services that solve the target customers' problems. Established firms too, such as LEGO, IBM (Hienerth et al, 2011), magazine publishers (Amit \& Zott, 2012) and Starbucks (Fitzgerald et al, 2014), are proactively undertaking digital transformation to design new differentiated customer-centric services with new attractive business models to counteract potential disruptions by startup firms - often from outside the incumbent's industry. But it is immensely difficult to succeed (Fitzgerald et al, 2014).

So firms must "comprehensively rethink their business models along the strategic dimensions of 
new products (services)" (Achtenhagen, Melin \& Naidi, 2013: 432). They need an integrated method to design new services and associated business models simultaneously to rapidly adapt to the changing market and external environments ahead of the competition. But, such an integrated design method does not yet exist (Crossan \& Apaydin, 2010; Kim et al, 2015).

The purpose of this article is to develop and evaluate a new theoretically-founded integrated design method for commercializing service innovation, named iSIM (integrated Service Innovation Method). It follows design science methodology (Hevner et al, 2004; Gregor \& Hevner, 2013). As iSIM is aimed at the practitioners as potential users, experienced practitioners are selected to evaluate its sense-making and potential utility to their respective businesses. Additionally, iSIM's efficacy is also evaluated using two exemplar case studies based on secondary data.

The theoretically-grounded iSIM contributes a new body of knowledge to the theories and practices of service innovation and business model innovation. By virtue of its holistic, crossdisciplinary, internally- and externally-aligned nature, iSIM allows practitioners to simultaneously, coherently and systematically design a new service and its attendant business model to co-create value with customers to meet their emerging needs. From the lens of practice and capabilities theories, we show how iSIM is constitutively linked to design praxis and ultimately to the firm's "dynamic service capabilities" explored in Kim et al (2015). iSIM governance framework and guidelines for its practice are defined to help managers incrementally introduce $i$ SIM into their firms' existing innovation practices.

The paper is organized as follows. Section 2 frames the research question in the context of its underlying developmental challenges. Section 3 describes the research structure which follows value co-creation principles to collaborate with selected practitioners in a theory-based 
but pragmatic pursuance of design science research methodology. Section 4 describes the theoretical constructs from diverse but related literatures that underpin iSIM. Section 5 synthesizes iSIM from these basic constructs and describes the $i \mathrm{SIM}$ specification in detail. The efficacy of iSIM is evaluated in Section 6 by two exemplar case studies using secondary data sources. Section 7 summarizes the selected practitioners' input to and evaluative feedback on iSIM. Section 8 discusses iSIM's managerial implications. Finally, Section 9 concludes by summarizing the article's core contributions and limitations; and suggests potential areas for further research.

\section{Framing the Research Question from the Literature}

To strategically frame the focal research question for $i \mathrm{SIM}$, it is necessary to first explicate the underlying problems confronting theoretical development of service innovation and business model (Dougherty, 2004; Gregor \& Hevner, 2013).

Technology is symbiotically interrelated with organization (Zammuto et al, 2007) and enables service innovation (den Hertog, 2000). Technology design defines the possibilities for potential user action but what matters is its actual usage as a service (Leonardi, 2011). This depends on "the intent of the actors enacting them" (Zammuto et al, 2007: 752). Technology-enabled innovation is more meaningful organizationally when viewed as a service, which is defined as a value-cocreating process of combining the technical with user competences (Gallouj and Weinstein, 1997), consistent with the service's strategic intent (Bettencourt, 2010). This suggests innovating new technology-enabled services is largely a socio-technical phenomenon requiring cross-disciplinary capabilities (den Hertog et al, 2010). iSIM must embrace socio-technical design requirements. 
Literature in the theories and practices of service systems design and implementation (Demirkan et al, 2011a; Demirkan et al, 2011b) is burgeoning as exemplified by recent works on various design frameworks or methods for service systems and networks (Agarwal and Selon, 2011; Patricio et al, 2011; Tan et al, 2011; Tung et al, 2014; Zadeh et al, 2014), and servicethinking framework (Hastings and Saperstein, 2013). Service design thinking as part of service innovation (Alam, 2006; Edvardsson et al, 2007; Edvardsson and Olsson, 1996) takes a crossdisciplinary holistic architectural perspective encompassing strategy, marketing, operations and information technology (den Hertog et al, 2010; Ostrom et al., 2010; Patricio et al, 2011; Voss and Hsuan, 2011; Scheider \& Spieth, 2013). The notion of platform thinking (Sawhney, 1998) has migrated to service platform thinking, initially popularized by credit-card industry and, lately by Apple's iTune and App Store and Amazon's advanced web service, (Gawer \& Cusumano, 2014; Lusch \& Nambisan, 2015). Digital technologies' ability to sustain 'network effect' is making service platform a feasible strategy for most firms (Smedlund, 2012; Yeo et al, 2010; Tiwana et al, 2010). Service architecture based on modularity theory (Baldwin \& Clark, 1997) is an industry-wide holistic concept suitable for modeling industry-wide platform design options (Voss \& Hsuan, 2009). However, neither service platform nor service architecture concepts have been addressed by extant service design frameworks or methods (e.g. Patricio et al, 2011; Tan et al, 2011). Service architecture and platform concept must be addressed by iSIM.

Mixed views still exist on the theoretical foundations of the basic definition and purpose of a business model (Arend, 2013; Bock et al, 2012; Zott \& Amit, 2013). A basic theoretical construct of business model is emerging (Baden-Fuller \& Haefliger, 2013; Casadesus-Masanell \& Ricart, 2010; Chesbrough, 2010; Osterwalder \& Pigneur, 2005; Zott and Amit, 2010; Teece, 2010; Demil \& Lecocq, 2010; Johnson et al, 2008). But, it lacks design method for 
operationalization (Teece, 2010; Achtenhagen et al, 2013; Schneider \& Spieth, 2013; Solaimani et al, 2013). There is even less knowledge on how to design the business model for external (evolutionary) and internal (technical) fitness (Siggelkow, 2002; Helfat et al, 2007). External fitness ensures business strategy and value proposition will co-evolve with changing customer needs. Internal fitness ensures the focal firm's and partners' resources and capabilities together with the constitutive activity system are orchestrated to bring to bear their complementarities or synergy effects while delivering on the espoused strategy and value proposition (Teece, 2010; Osterwalder \& Pigneur, 2010; Johnson et al, 2008; Zott \& Amit, 2013). iSIM must address business model evolutionary fitness design.

Service innovation and business model (commercialization) are two intricately interrelated customer value creation concepts with many overlapping concerns (Chew, 2014b). Yet, they have been treated by the extant literatures in silos as though they were distinct, independent disciplines. Moreover, customer value creation is conceptualized by service-dominant logic in service innovation but goods-dominant logic in business model literatures respectively (Chew, 2014b). iSIM must harmonize these differences.

The embryonic and evolving nature of design practices for both service system (Patricio et al, 2011) and business model design (Teece 2010; Achtenhagen et al, 2013; Osterwalder \& Pigneur, 2013; Schneider \& Spieth, 2013) poses another challenge for joint theory development. That is they lack a common ground for sharing understanding (Dougherty, 2004). Yet, there is a practical need for cross-disciplinary and industry-wide architectural perspectives of service innovation and business model involving strategy, marketing, operations and information technology. 
Consequently iSIM must take a holistic perspective on the fundamental relationships of its theoretical constructs that will overcome the above challenges to enable a consistent and coherent integrated design of new service and business models to meet emerging or changing customer needs. To that end, we frame the research question for $i$ SIM as follows:

How can a theoretically derived multidisciplinary integrated method enable the simultaneous design of innovative service and business model that is end-to-end aligned with emergent customer needs and business strategy?

\section{Research Design}

The research question is well suited to design science research method (Hevner et al, 2004; Gregor \& Hevner, 2013) where $i$ SIM is the artifact or 'the service' to be designed specifically for ultimate use by practitioners ('the users') in their respective businesses and industries. $i$ SIM will be developed theoretically from diverse interrelated fields of strategic management, service science, information systems, and organization science. It will be evaluated by practitioners to ensure it makes sense and has potential utility to their businesses through interpretive qualitative interviews. This means expert practitioners need to selected and engaged over the life of the research in order to leverage their practice knowledge and experience of service innovation and business model design to co-produce and co-evaluate the new theoretically derived iSIM. To that end, we draw on a combination of the Crossan and Apaydin (2010) research method for systematic synthesis of a multi-dimensional theoretical innovation framework, and the Nenonen and Storbacka (2010) research method for engaging selected practitioners (experts) to iteratively incorporate their input on shaping and feedback on sense-making of $i$ SIM. We then overlay the combined methods over the Hevner et al (2004) design science research method such that the 
proposed $i$ SIM is co-created and co-evaluated with the selected practitioners so as to fulfill their expected practice requirements. Further, consistent with Nenonen and Storbacka (2010), we follow Eisenhardt (1987), Eisenhardt \& Graebner (2007) and Yin (2007) to theoretically sample (select) the practitioners and to govern the practitioners' interview protocols. The resultant research design is summarized below as shown in Figure 1.

The above theoretical consideration together with the author's prior new service development practice experience informs the need to review multi-disciplinary literatures in order to frame the research question. Practitioners are theoretically sampled as explained above. The selected practitioners' input at the inception of the research combined with the author's own expert knowledge confirms the scope of the research question, and helps shape the broad practice requirements for $i$ SIM and identify relevant papers from diverse literatures for data collection (Nenonen and Storbacka, 2010), from which we then conduct data analysis and synthesis in line with Crossan and Apaydin (2010). Meta-analysis is first applied to identify pattern-matching and explanation building (Yin, 2007) which is then followed by in-depth theoretical analysis and synthesis of causality relationships between key service-design underlying theoretical constructs. The developing $i$ SIM ('prototype') is presented to the practitioners to seek their feedback regarding its utility and sensibility. Upon reaching structural stability, a formal workshop is then arranged to compare and contrast iSIM with the selected practitioners' knowledge of extant service and business model design methods to confirm iSIM's overall congruence with the practitioners' utility expectations. On confirmation of the congruence at the conclusion of the workshop, a formal plan is then scheduled for adoption and subsequent customization and application of $i$ SIM to match each selected practitioner's business requirements. This step constitutes the next phase of the research, which is outside the scope of this article (hence not shown in Figure 1). This 
phase comprises a three-year (2015-2018) action research program involving knowledge transfer to and capability development of the selected practitioner's firm to enable them at the completion of the program to systematically, effectively and consistently design and commercialize new service innovations.

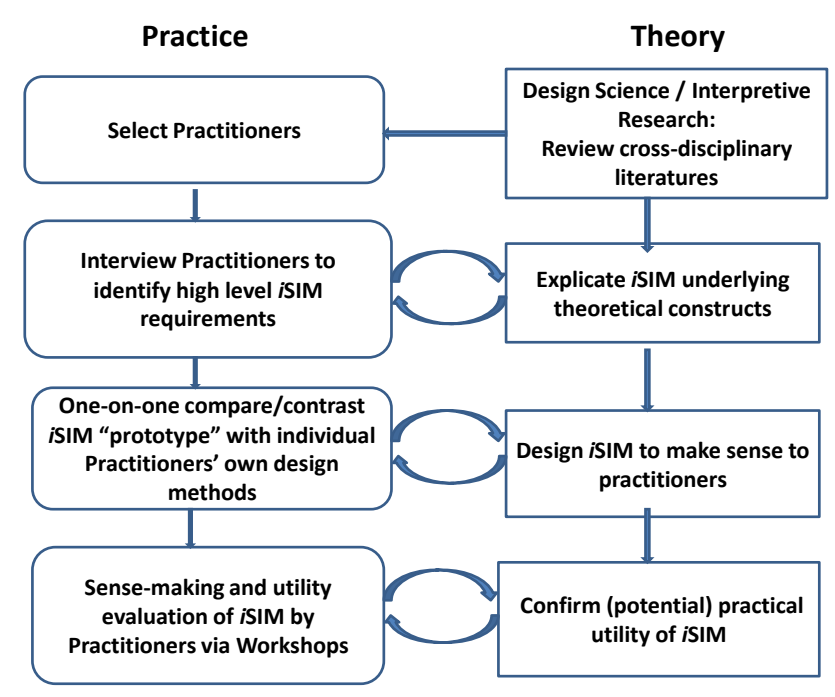

Figure 1: Research Design

\section{Underlying Theories of iSIM}

\subsection{Value Co-creation}

Customer value co-creation is central to service innovation (Rubalcaba et al. 2012). Value is cocreated by the customer by integrating the provider's competences and resources with its own during usage of the service over time through a socially constructed customer process (Edvardsson et al. 2011; Gronroos \& Voima, 2013), and through the customer's accumulation of experiences (Helkkula et al, 2012). The customer is proactive in this service interaction. Customer's service experience has a lifecycle of engagement (mutual value propositions aligned) and disengagement (misaligned) (Chandler \& Lusch, 2014). The provider's role is to facilitate the custom- 
er's value creation (Gronroos \& Voima, 2013). Thus understanding the customer's valuecreating activities in their 'journey' (Rawson et al, 2013) is the key to maximizing co-creation opportunities and attaining superior service experience (Heinonen,et al 2010; Mickelsson, 2013 ). The provider may also adopt open innovation practice (Johannessen \& Olsen, 2010; Chesbrough \& Davies, 2010) to orchestrate and integrate the provider's own business ecosystem of complementary resources (Zahra \& Nambisan, 2012) to help co-create greater customer value. iSIM must therefore support selective participation by suppliers, partners and customers with the provider in the overall value co-design process.

The provider may extend the dialogical 'value co-creation' process beyond value-in-use activities to include co-production activities by engaging the customer as a co-producer (or codesigner) at different points of the production (design) process. This would enhance mutual value propositions alignment. Co-production and value-in-use are distinct processes (practices) which must be disambiguated (Galvagno \& Dalli 2014; Rajan and Read, 2014). Customer's contributions to value co-creation (both co-production and in use) are contingent on factors such as the service offering type (Moeller et al (2013), the different stage of new product development (Hoyer et al, 2010), and the customer's resource contributions (Rubalcaba et al. 2012; Jaakola \& Alexander, 2014). iSIM must facilitate customer service co-production as well as value cocreation activities to tailor overall service experience the customer's needs or preferences.

\subsection{Value Co-creating Business Model}

There is not yet a commonly agreed definition for and perspective on business model (George \& Bock, 2011; Arend, 2013; Zott \& R. Amit, 2013). From a variety of popular business model constructs (Baden-Fuller \& Haefliger, 2013; George \& Bock, 2011; Casadesus-Masanell \& Ricart, 2010; Chesbrough, 2010; Nenonen \& Storbacka, 2010; Osterwalder \& Pigneur, 2005; Zott \& 
Amit, 2010; Teece, 2010; Demil \& Lecocq, 2010; Johnson et al, 2008), three common denominators $^{1}$ of business model can be discerned from which value co-creation can be more systematically 'designed' in line with the above service innovation model:

- the Customer (the target of value creation) - delineating the customer type and the customer value proposition that meets their needs,

- the Organization (how work is organized to co-create value with the customer) delineating how the firm engages the customer and mobilizes its resources and competencies for the benefit of and in conjunction with the customer so as to deliver on the value proposition, and

- Monetization also variously known as 'profit formula' (Johnson et al, 2008), 'revenue model' (Zott \& Amit, 2010), or 'revenue streams' (Osterwalder \& Pigneur, 2010) delineating how the firm captures value by getting paid for the job done or service performed via a creative so-called $\mathrm{m}$-sided $(\mathrm{m}=1,2$, or 3 , etc. depending on number of types of customer served by the business model) revenue model (Eisenmann et al, 2006).

In sum, the business model is defined as the business logic of the firm (Casadesus-Masanell \& Ricart, 2010; Zott \& Amit, 2010) through which it co-creates value with customers (Vargo \& Lusch, 2004), and gets paid in return (Teece, 2010; Osterwalder \& Pigneur, 2010). The business logic defines the unique business activities (processes) that the firm performs to create and capture value better than the competition (Casadesus-Masanell \& Ricart, 2010; McGrath, 2010; Osterwalder \& Pigneur, 2010; Zott \& Amit, 2010). In general, it includes the supply-side ecosystem of partners and suppliers (Adner \& Kapoor, 2010; Dougherty \& Dunne, 2011; Zahra \&

\footnotetext{
${ }^{1}$ George and Bock (2011) too define business model as comprising three elements: resource structure, transactive structure, and value structure. As our model is focused on customer value co-creation, Customer constitutes a core construct in our model. The organization construct combines both resource structure and transactive structure of George \& Bock (2011) conceptualization. Monetization is equivalent to George \& Bock's (2011) value structure. We regard the cost structure to be directly dependent on organization design. Thus the dynamic interaction between Organization and Monetization designs is an important business model design issue.
} 
Nambisan, 2012; Solaimani et al, 2013) to broaden its accessible complementary resources and competencies for customer value creation. And it mobilizes the Customer to make it easy for them to integrate the Organization's (service system's) resources and competencies with their own resources and those of their customer-side ecosystem of complementary partners (Priem et al, 2013), as illustrated in Figure 2. The service system entities engage in knowledge-based interactions to co-create value, where value is, on one hand, determined and co-created by the Customer in use (Grönroos \& Voima, 2013) and, on the other, captured by the Organization via payment through an m-sided revenue model. The captured value is known as exchange value in service model (Vargo et al, 2008) and 'Monetization' in business model as shown in Figure 2.

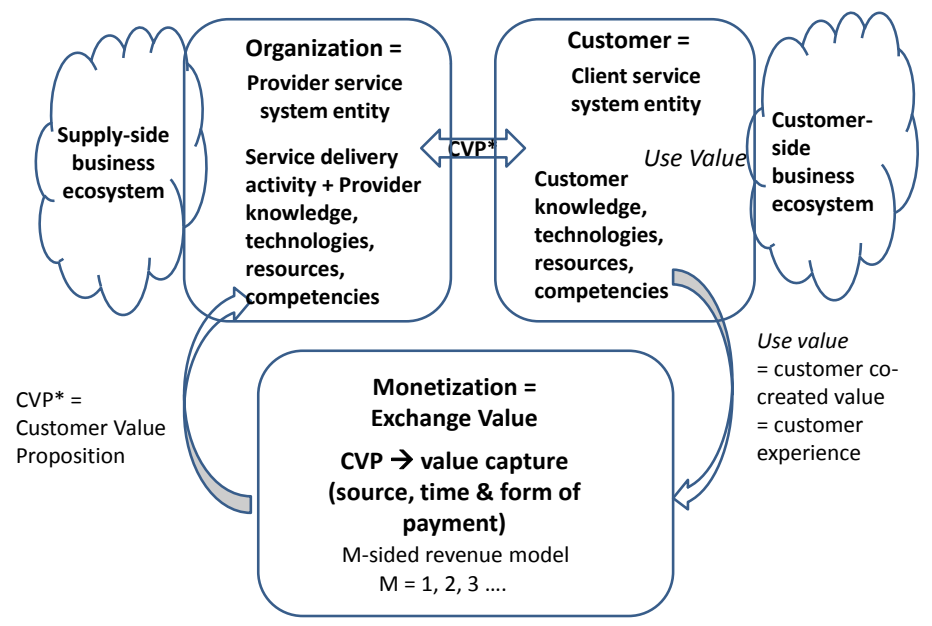

Figure 2: A Value Co-creation View of Service Business Model

The customer value proposition (CVP) is encapsulated in the 'service concept' which defines what the service (e.g. of a new technology) is about and how it satisfies customer needs (Fynes \& Lally, 2008; Goldstein et al, 2002). With the theoretical constructs of service and business model now unified, customer value co-creation process for business model is exactly the same as the above (4.1). The customer experience, however, is determined by a composite of benefits and 
burdens (or costs) (Fitzsimmons \& Fitzsimmons, 2010). For instance, in a two-sided business model, the end-user who gets to use the free Google search service is often 'burdened' with the advertisers' 'ad messages' intermingled with the searched information - creating a tension known as 'monetization intensity' (Casadesus-Masanell \& Zhu, 2013). iSIM has to account for both business logic (activity system) and monetization factors of business model design including especially their interdependency.

\subsection{Service Innovation Process}

Service innovation is about designing new ways (resources and practices) of helping customers create greater value (Michel et al, 2008; Vargo \& Lusch, 2008a). It provides "new resources, available to customers in value constellations" (Rubalcaba et al, 2012: 708) to create superior value (Michel et al, 2008; Normann \& Ramirez, 1993) and make them better off (Grönroos \& Voima, 2013). It is about how new value propositions (and service concepts) can be designed via improving existing or creating new practices and/or resources, or by means of integrating practices and resources in new ways (Skalen et al, 2014). Service innovation requires not only having the right resources, but also established methods and practices for integrating these resources into attractive value propositions. Similarly, business model innovation is centered on purposeful design of the firm's new activity system (business logic) to deliver on the promised value to the customer (Amit \& Zott, 2012; Zott \& Amit, 2010). Service and business model innovation would entail new value proposition or new service concept (or its improvement), new practice or new organizational or technological service delivery system, or new customer interaction (interface), 
new resource or new value system/business partners, or new revenue model ${ }^{2}$ (den Hertog et al, 2010). The iSIM design practice must accordingly be capable of creating one or all these service innovation outcomes. It will be performed in stages: problem finding (analysis), problem solving (service design) and operating (value realization) practices (Dorner et al, 2011; Patricio et al, 2011; Payne \& Frow, 2014; Skalen et al 2014).

\subsection{Service Innovation Organizational Capabilities}

Organizational capabilities are composed of "socially complex routines that determine the efficiency with which firms physically transform inputs into outputs" (Collis 1994: 145). Designing is a situational, contingent and socially complex routine or practice performed by agency (the designer). Organizational capabilities such as innovation capabilities are a "firm-specific and timeand space-contingent ability to perform a particular productive activity" (Jacobides \& Winter 2012: 1365). Innovative organizational capabilities are critical antecedents to service innovation (Kim et al, 2015; Karpen et al, 2012; Dorner et al, 2011; den Hertog et al, 2010). Specifically, they include resource integration, reconfiguration and extraction capabilities (Kim et al, 2015), collaborative capability to co-create value with customers and partners, dynamic customer orientation capability to enable entrepreneurship (Ordanini \& Parasuraman, 2011), and absorptive capability (Zahra and George, 2002) to underpin employee collaboration and organizational renewal. To cultivate and nurture such an open innovative culture, firms need to practice open leadership ( $\mathrm{Li}, 2010)$.To practice co-creation, at a micro-level, firms need a combination of individuated, relational, ethical, empowered, developmental, and concerted strategic interactionbased organizational capabilities (Karpen et al, 2012). At a meta-level, firms need dynamic ser-

\footnotetext{
${ }^{2}$ This incorporation of a business model construct into the service model construct supports the new integrated design method
} proposed in this article. 
vice innovation capabilities comprising: sensing and value proposition design capability; service concept design capability; modular service (re)configuration capability; customer or stakeholder co-production/co-design capability; service solution scaling and stretching (or extractive) capability; and learning and adapting capability (den Hertog et al, 2010; Kim et al, 2015). Holistically, these capabilities interrelate with one another and need overall coordination to perform service innovation design effectively (Kim et al, 2015). We therefore define service architecture as part of $i$ SIM to serve as a holistic design governance reference model to ensure internal and external configurational fitness (Helfat et al, 2007) of the innovation (design outcome) and its global optimization (Zott \& Amit 2013). The proposed iSIM must define the processes or routines through which these dynamic service innovation capabilities (Kim et al, 2015) will be performed and constitutively produced by designers (the actors) in creating new innovations.

According to practice theory, it is actors' everyday actions that are consequential in the duality of performing and producing the socially complex routines (Dougherty, 2004; Whittington, 2006; Feldman \& Orlikowski 2011). Thus viewing iSIM as practice "is oriented to what actors do as opposed to something that organizations have" (Feldman \& Orlikowski 2011: 1241). To that end, practicing $i$ SIM is concerned with the dynamic relations and performance nature of service 'designing and using' (Dougherty, 2004; Feldman \& Orlikowski 2011). "The social aspects of relationships between business model participants" are also recognized as a critical business model design factor that warrants further research (Zott \& Amit 2010: 224). The analytic focus is on "understanding the myriad of interactions" through which design "unfolds over time" (Jarzabkowski 2005: 5). Service innovation as practice then is conceptualized as a "problem of value creation" guided by strategy, which is "an active, situated and coherent flow of problem setting and problem solving activities" routinely reflecting in action to learn of the impact of using 
the new solution (Dougherty, 2004: 46). The proposed iSIM must likewise support this coherent flow of problem setting and solving activities, instantiating a portfolio of dynamic service innovation capabilities such as those identified by den Hertog et al (2010) and Kim et al (2015).

\subsection{Service Platform and Architecture}

The above integrative conceptualization of a service system and business model is founded on a common value-creating architectural construct known as the service activity system (George \& Bock, 2011; Zott \& Amit, 2013). The activity system is conceptualized as an industry-wide network interconnecting the customer's and the firm's internal and external constellations of value co-creating activities, as shown in Figure 2. A theoretical framework is required for studying and designing such an industry-wide network of activity system (Thomas et al, 2014). This entails an architecture view (Baldwin \& Clark, 1997) and platform or ecosystem thinking (Gawer \& Cusumano, 2014; Lusch \& Nambisan, 2015; Sawhney, 1998) which aim to design the firm's activities and offerings to achieve leveraged growth by identifying and consistently reusing shared assets, designs, and standards in developing all future new services. The proposed iSIM should adopt modularity as both a process and a content concept (MacDuffie, 2013).

A firm-specific modularity and interface standards need to be architecturally defined for a service platform (Meyer \& DeTore, 2001), which enables rapid creation / configuration of families of services systematically to match customer-value creation requirements (Gawer \& Cusumano, 2014; Lusch \& Nambisan, 2015). A service platform could be closed to only companyinternal developers, known as internal platform, or open to external third-party service developers, known as external platform as exemplified by Apple's App Store (Gawer \& Cusumano, 2014). It enables and sustains service ecosystem value co-creation via 'actor-to-actor' collabora- 
tion mechanisms (Lusch \& Nambisan, 2015). Open versus closed platform service development is a business-model 'ecosystem design' strategic choice (Eisenmann et al, 2006; Gawer \& Cusumano, 2014; Iansiti \& Levien, 2004; Isckia, 2009; Sawhney, 1998; Thomas et al, 2014; Zahra \& Nambisan, 2012). The proposed iSIM must therefore incorporate the service platform / service architecture concept, where architecture is defined "as a system of elements and their relationships which embodies the structural design, component mapping, and subsystem interfaces" (Thomas et al, 2014: 207). The iSIM service architecture is an overarching reference model for guiding end-to-end design processes of customer type/value proposition, service concept, service system and experience design, as well as monetization. As induced in Section 4.4 above, it also serves as a holistic design governance reference model to ensure internal and external configurational fitness of the integrated service and business model design.

\subsection{The iSIM Model}

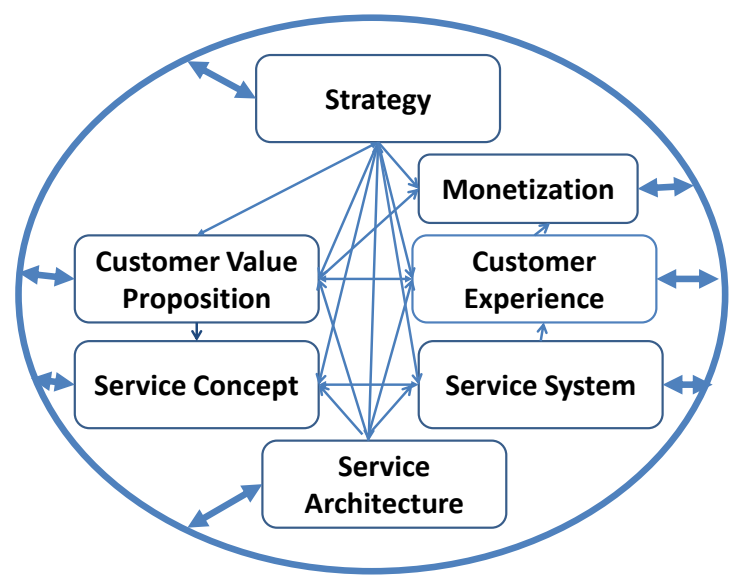

Figure 3: The iSIM Model 
A coherent theoretical flow of design activities can be discerned from the above disposition of the fundamental theoretical constructs for iSIM. They can be used to identify the constitutive process elements of the proposed iSIM. Candidate patterns of activity flows are discerned from the staged value co-creation, service innovation processes and organization capabilities. In particular, from the above theoretical development we identify seven process elements, ranging from macro (strategic) to micro (operational) level of design detail: strategy, service architecture, monetization, customer type / value proposition, service concept, service system, and customer experience. The interrelated constructs of design processes can be configured into an iSIM model as illustrated in Figure 3. The interrelationships between all design-process elements, representing design (criteria, objectives or constraints) knowledge exchange, are highlighted by the double-arrows linked together by the ring. Strategy and service architecture design-process elements are the macro overarching guides governing the end-to-end design integrity. Service architecture reflects and becomes the business strategy (Ross et al, 2006) in terms of 'designer language' of service modularity interface and potentially platform standards (Tiwana et al, 2010). But strategy (hence service architecture) is conceived from deep understanding of customer journey and pain points together with the unmet needs - a strongly market-driving, outside-in, strategic design paradigm. Thus the customer value proposition (supporting the strategy) mirrors the desired customer experience by designing it 'backward' from first envisioning what the unique superior customer experience should be when the new service offering (yet to be designed) had successfully eradicated the customer pain points experienced during their journey within their value constellation.

Design practice is a knowledge and information intensive social process. iSIM is predicated on purposeful integration of interdependent design knowledge between the seven design process 
elements. Design knowledge (artifact) produced by one design process element is transferred to the next design process element as 'design needs' for additional processing (i.e. direct consumption for fine-grained designing) or as 'design constraints' to guide design decision-making in the next design process element. For instance, in Figure 3, CVP design output defines the design needs of service concept which turn defines the design needs of service system; while service architecture defines the design constraints for service concept and service systems in terms of modularity requirements. A coherent flow of 'purposeful' design knowledge will therefore take place in the course of social construction a new service with $i$ SIM. The path taken by each knowledge flow is situational and contextual which is contingent on service business strategy, organizational maturity, and the nature of service innovation (whether an exploratory or exploitative) in question. Thus the path is not necessarily linear, nor unidirectional.

\begin{tabular}{|c|c|c|c|c|c|c|c|}
\hline & strategy & $\begin{array}{c}\text { Service } \\
\text { architecture }\end{array}$ & Monetization & $\begin{array}{l}\text { Customer type } \\
\text { \& CVP }\end{array}$ & $\begin{array}{l}\text { Service } \\
\text { concept }\end{array}$ & Service system & Experience \\
\hline strategy & & $\begin{array}{l}\text { Industry } \\
\text { position; } \\
\text { business logic; } \\
\text { platform } \\
\text { choice }\end{array}$ & $\begin{array}{l}\text { Platform } \\
\text { choice; } \\
\text { m-sided } \\
\text { revenues per } \\
\text { business logic }\end{array}$ & $\begin{array}{l}\text { Business logic } \\
\& \text { CVP per } \\
\text { customer type } \\
\text { per platform }\end{array}$ & $\begin{array}{l}\text { Business logic } \\
\text { \& CVP per } \\
\text { customer type } \\
\text { per platform }\end{array}$ & $\begin{array}{l}\text { Business logic } \\
\text { \& CVP per } \\
\text { customer type } \\
\text { per platform }\end{array}$ & $\begin{array}{l}\text { Business logic } \\
\text { \& CVP per } \\
\text { customer type }\end{array}$ \\
\hline $\begin{array}{l}\text { Service } \\
\text { architecture }\end{array}$ & $\begin{array}{l}\text { E2E fitness of } \\
\text { modular } \\
\text { business logic } \\
\text { per industry \& } \\
\text { platform layer }\end{array}$ & & $\begin{array}{l}\text { M-sided } \\
\text { revenue } \\
\text { model per } \\
\text { modular arch. } \\
\text { layers \& } \\
\text { external fit }\end{array}$ & $\begin{array}{l}\text { Modular cust. } \\
\text { Interface; } \\
\text { componentize } \\
\text { d CVP \& } \\
\text { external fit }\end{array}$ & $\begin{array}{l}\text { Modular } \\
\text { concept } \\
\text { design with } \\
\text { CVP at cust. } \\
\text { interface \& } \\
\text { E2E fit }\end{array}$ & $\begin{array}{l}\text { Modular } \\
\text { resource \& } \\
\text { system model } \\
\text { delivering CVP } \\
\text { \& E2E fit }\end{array}$ & $\begin{array}{l}\text { Experience } \\
\text { model delivers } \\
\text { CVP; customer } \\
\text { learning syst. } \\
\text { \& external fit }\end{array}$ \\
\hline Monetization & $\begin{array}{l}\text { Monetization } \\
\text { intensity } \\
\text { dynamics }\end{array}$ & $\begin{array}{l}\text { Monetization } \\
\text { intensity } \\
\text { dynamics }\end{array}$ & & $\begin{array}{l}\text { Monetization } \\
\text { intensity } \\
\text { dynamics }\end{array}$ & $\begin{array}{l}\text { Monetization } \\
\text { intensity } \\
\text { dynamics }\end{array}$ & $\begin{array}{l}\text { Monetization } \\
\text { intensity } \\
\text { dynamics }\end{array}$ & $\begin{array}{l}\text { Monetization } \\
\text { intensity } \\
\text { dynamics }\end{array}$ \\
\hline $\begin{array}{l}\text { Customer type } \\
\text { \& CVP }\end{array}$ & $\begin{array}{l}\text { Alignment to } \\
\text { CVP; external } \\
\text { fitness criteria }\end{array}$ & $\begin{array}{l}\text { Alignment to } \\
\text { CVP; external } \\
\text { fitness criteria }\end{array}$ & $\begin{array}{l}\text { Alignment to } \\
\text { CVP; external } \\
\text { fitness criteria }\end{array}$ & & $\begin{array}{l}\text { Alignment to } \\
\text { CVP; external } \\
\text { fitness criteria }\end{array}$ & $\begin{array}{l}\text { Alignment to } \\
\text { CVP; external } \\
\text { fitness criteria }\end{array}$ & $\begin{array}{l}\text { Alignment to } \\
\text { CVP; external } \\
\text { fitness criteria }\end{array}$ \\
\hline $\begin{array}{l}\text { Service } \\
\text { concept }\end{array}$ & $\begin{array}{l}\text { Strategic } \\
\text { adjustment } \\
\text { requirements }\end{array}$ & $\begin{array}{l}\text { Architectural } \\
\text { adjustment } \\
\text { requirements }\end{array}$ & $\begin{array}{l}\text { Value creation } \\
\text { dynamism } \\
\text { requirements }\end{array}$ & $\begin{array}{l}\text { Alignment of } \\
\text { internal to } \\
\text { external } \\
\text { fitness }\end{array}$ & & $\begin{array}{l}\text { Service system } \\
\text { E2E fitness } \\
\text { design } \\
\text { requirements }\end{array}$ & $\begin{array}{l}\text { Alignment of } \\
\text { internal to } \\
\text { external } \\
\text { fitness }\end{array}$ \\
\hline Service system & $\begin{array}{l}\text { Strategic } \\
\text { adjustment } \\
\text { requirements }\end{array}$ & $\begin{array}{l}\text { Architectural } \\
\text { adjustment } \\
\text { requirements }\end{array}$ & $\begin{array}{l}\text { Systemic } \\
\text { value creation } \\
\text { dynamism } \\
\text { requirements }\end{array}$ & $\begin{array}{l}\text { Alignment of } \\
\text { internal to } \\
\text { external } \\
\text { fitness }\end{array}$ & $\begin{array}{l}\text { Alignment of } \\
\text { internal to } \\
\text { external } \\
\text { fitness }\end{array}$ & & $\begin{array}{l}\text { Alignment of } \\
\text { internal to } \\
\text { external } \\
\text { fitness }\end{array}$ \\
\hline Experience & $\begin{array}{l}\text { Customer } \\
\text { learning re } \\
\text { external } \\
\text { fitness }\end{array}$ & $\begin{array}{l}\text { Customer } \\
\text { learning re } \\
\text { external } \\
\text { fitness }\end{array}$ & $\begin{array}{l}\text { Customer } \\
\text { learning re } \\
\text { external } \\
\text { fitness }\end{array}$ & $\begin{array}{l}\text { Customer } \\
\text { learning re } \\
\text { external } \\
\text { fitness }\end{array}$ & $\begin{array}{l}\text { Customer } \\
\text { learning re } \\
\text { external } \\
\text { fitness }\end{array}$ & $\begin{array}{l}\text { Customer } \\
\text { learning re } \\
\text { external } \\
\text { fitness }\end{array}$ & \\
\hline
\end{tabular}

Figure 4: iSIM's Interrelationship Map between Design Process Elements 
From the iSIM model (Figure 3), a holistic map of the design knowledge interrelationships between the seven design process elements can be preliminarily tabulated, as shown in Figure 4. The theoretical relationships are mapped as a flow, viewed row by row, from left-hand column to each cell of the columns the row in question intersects with. For instance, the first row, strategy, links to (and influences) each cell of service architecture, monetization, customer type/CVP, service concept, service system and service/customer experience. Normative practice method and specific knowledge interrelationships for each design process element will be detailed as integral part of $i$ SIM specification in Section 5. The knowledge interrelationship map of Figure 4 together with the prescription of $i$ SIM in Section 5 constitutes the formal ('know-how') specification of iSIM practice (Whittington, 2006; Feldman \& Orlikowski 2011) or iSIM ostensive routine (Feldman, 2000; Feldman \& Orlikowski 2011). Knowledge transfer between design process elements is contingent on effective practice of 'reflection-in-action' by the practitioner in practicing the elemental design practice (Dougherty, 2004; Whittington, 2006). Practitioners' critical reflection on their practice experience (praxis) and on the impact of the service design (outcome) is a fundamental knowledge management and dynamic organizational capability development mechanism (see Section 5.8). Its effective performance depends on a service- and designthinking (Hastings and Saperstein, 2013), and organizational culture which must be led and nurtured by the focal firm's top leadership.

The iSIM interrelationship map offers practitioners an initial guide for ensuring, end-to-end, internal and external fitness of a new service and business model innovation. iSIM practice will be subject to further refinement during the planned full-scale field application (known as the praxis) of iSIM with designers of selected organizations (known as the practitioners) in 20152018. This iterative practice-practitioner-praxis cycle of refinement of the integrated service de- 
sign practice is a natural social construction process of practice or routine (Whittington, 2006;

Feldman \& Orlikowski 2011). Once adopted and practiced by an organization, iSIM will over time, through the iterative cycle of 'practice-practitioner-praxis' organizational learning and related absorptive capacity, become the organization's own unique dynamic capability moderated by its culture.

\section{The iSIM for Commercializing Service Innovation}

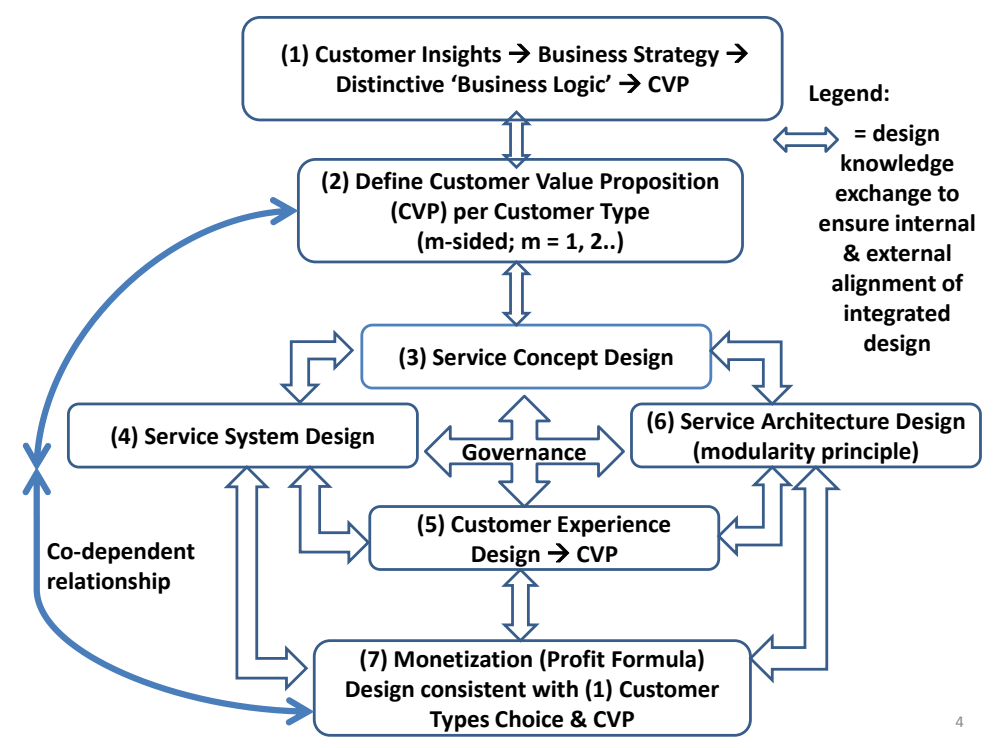

Figure 5: The iSIM End-to-end Design Processes

(Adapted from Chew (2014b))

From the iSIM model of Figure 3 and design-process elements interrelationship map of Figure 4, we can now answer the research question and specify $i$ SIM for commercializing service innovation. iSIM (Figure 5) is fundamentally a strategic tool. It is anchored on the firm's mission, service strategy and brand value, focused on meeting extant and emerging customer needs, comprising seven holistically interrelated practices of: (1) service business strategy design, (2) customer type and customer value proposition design, (3) service concept design, (4) service 
system design, (5) customer experience design, (6) service architecture design, and (7) monetization design. The seven iSIM practice elements and their underlying theories and principles are described below individually. While they are presented, for simplicity and clarity sake, sequentially, these practices are actually often performed in-practice iteratively and holistically - contingent on the practicing service firm's and customer's situation, maturity and strategy.

\subsection{Service Strategy Design}

Strategy (step 1) is designed (by C-level leadership team) to fulfill the firm's vision and mission. To that end, it defines the firm's business logic, its platform choice, and corresponding m-sided market model. Service strategy defines the overarching directional guide for all design process elements in iSIM, as illustrated in the holistic model in Figure 3.

Step 1 strategy is closely linked to step 2 customer type and value proposition design process. In some startup firms these two steps are often indistinguishable and performed iteratively; sometimes, starting with customer definition first to get value proposition align with customer expectations before firming up on designing the broader longer term strategy. For instance, service strategy, coupled with customer type and value proposition design, could be successful designed (Bettencourt, 2010) in four steps: (a) choose the innovation focus, e.g. a radical service innovation or incremental service delivery innovation, and the target customer types, (b) uncover customer needs in terms of jobs to get done and outcomes expected, (c) prioritize customer needs and design the corresponding distinctive customer value propositions (CVP), (d) develop a service strategy (i.e. the distinctive business logic and strategic service concept requirements) to fulfill the high priority customer needs. A successful service strategy fits what the customer will 
value with what the company can deliver - mutual capabilities alignment (Maglio et al, 2009) or service-market fit (Helfat et al, 2007). These steps are typically marketing-led in collaboration with IT and finance executives.

\subsection{Customer-type and Value Proposition Design}

Step 2 customer-type and value proposition (CVP) design and step 7 monetization design are codependent factors of business model design. They are analyzed and chosen by using competitive game theory and contingency theory. These steps are typically marketing-led in collaboration with IT and finance executives. Customer type and value proposition (CVP) design process element defines the external fitness requirements for all other design process elements as shown in the holistic iSIM model in Figure 3. While these steps follow from the service strategy, their designs will iterate with the service concept ideation process (below) and can only be finalized when service concept (being the detailed functional specification of the CVP) has taken shape in satisfying the customer value constellation value expectations.

Customer types would be chosen on the basis of m-sided markets (Eisenmann et al, 2008) where the choice of $\mathrm{m}=1,2$ or 3 , etc. depending on the revenue (monetization) model preferred to be decided in Step 7. Above all, an appropriate value proposition (this step) and service concept (step 3) must be designed (and delivered) to match the needs of each customer type. These are addressed by turn in the remainder steps below.

\subsection{Service Concept Design}

A marketing-led practice (supported by IT and operations executives), step 3 service concept design process element designs the service logic (e.g. Dell's "build-to-order" logic (McGrath, 
2010)) in line with the business logic and strategic intent defined in step 1 in order to fulfill the high-level customer value proposition designed in step 2. The design process ascertains in detail, through customer insights analysis and/or customer co-production engagement (Gronroos \& Voima, 2013; Galvagno \& Dalli 2014; Rajan \& Read, 2014), what the expected customer value is: namely, service benefits/experience expectations, participation activities, emotional and perceptual components, service process, physical environment, and people / employee / customer (Fynes and Lally, 2008) and how it will co-create value with the customers to satisfy their value constellation needs (Clarke et al, 2000; Patricio et al, 2011; Gronroos \& Voima, 2013; Galvagno \& Dalli 2014; Rajan \& Read, 2014). It relates to service architecture (step 6) which guides service system design (step 4); and defines the service governance - i.e. the decision rights and the decision making process for (step 4) service system design, planning and implementation (Goldstein et al, 2002; Patricio et al, 2011). For examples, at the strategic planning level (Marketing-led), the service concept drives design decision for new or redesigned service system (and business model) - the extent of step 4 service system design depends on whether the step 3 service concept design is of exploratory of exploitative nature. At the operational level (IT- or Operations-led) it defines how the service delivery system implements the service strategy (business logic and platform thinking) and how to determine appropriate performance measures for evaluating service system design. At the service recovery level (Operations-led), it defines how to design and enhance service encounter interactions (Patricio et al, 2011).

Where service concept has been co-produced with or validated by customers the resultant design knowledge (customer value requirements and constraints) is used to guide the other design process elements as follows (summarized in the interrelationship map in Figure 4):

- verify the external fitness of CVP (step 2); 
- provide the internal and external fitness end-to-end requirements for service system design (step 4) and service/customer experience design (step 5);

- reassess if adjustment is required on the espoused service strategy (step 1) and corresponding service architecture (step 6); and

- define the value creation dynamism requirements or tension constraints for the monetization design process element (step 7).

\subsection{Service System Design}

Service system design (step 4) at service delivery level is an IT/operations-led cross-disciplinary endeavor. It starts with the customer/user and defines how the service will be performed using human-centered and user-participatory methods to model the service performance (Patricio et al, 2011; Holmlid and Evenson, 2008). Service innovation, and thus the step 4 service system design process element, could be exploratory requiring comprehensive service system radical redesign (including potentially organization redesign and realignment in which case it becomes a $C$-level leadership-led cross-disciplinary endeavor) affecting all dimensions of the den Horteg et al (2010) model (see section 4.4), or exploitative requiring only redesign of service delivery system and/or interface level. Step 4 usually involves designing new service delivery processes (end-to-end from suppliers/partners to the Customer) in line with the business logic of step 3 service concept and the strategic intent of step 1 to consistently fulfill the CVP by facilitating co-creation of the proposed value and service experience (in step 5) by the customer through ease of integrating the firm's technologies, resources and capabilities with the customer's own (e.g. Patricio et al, 2011).

Service design must address strategic service issues such as marketing positioning and the preferred type of customer relationship, in line with the strategic intent of the service 
organization. Service governance is also required to monitor the service qualities and financial performance against the design outputs. Design constraints for service delivery system, prescribed by service architecture design process element, must address multiple interrelated factors: standardization for modularization; transaction volume per time period; locus of profit control; types of operating personnel; types of customer contacts; quality control; orientation of facilities; and motivational characteristics of management and operating personnel (Goldstein et al, 2002). The service delivery system fulfills the firm's strategic service vision and is designed by means of service blueprinting (Bitner et al, 2008; Fitzsimmons \& Fitzsimmons, 2010; Patricio et al, 2011). Service blueprinting is a map or flowchart of all the transactions constituting the service delivery process. The map identifies: the potential fail-points; the line of interaction between client and provider known as service encounters where lean consumption (Womack \& Jones, 2005) is a key design requirement to facilitate customer value co-creation (step 5); the line of visibility - above it employees actions are visible to the customer where adaptability is a key design requirement for personalized experience; below it is the back-stage and the internal line of interactions where lean, standardized modularization of production or operations processes is a key design requirement (Bitner et al, 2008; Fitzsimmons \& Fitzsimmons, 2010). Taking such an end-to-end view also allows the service to be co-designed with the stakeholders (including suppliers and partners) incorporating a combination of changes across process, organization, technology, and tool in an integrative manner (Maglio et al, 2006).

Service design must include strategies for handling service variability to ensure sustained level of service quality expected by customers (Glashko \& Tabas, 2009). For instance, to manage an unexpected deviation from normal service encounter, the service design (per service strategy and governance) may incorporate the notion of service personnel empowerment which grants them the 
discretion to recover from service deviation (failure) by offering compensations or alternative solutions to the customer to minimize adverse impacts to the customer (Normann \& Ramirez, 1993). Finally, service design needs to achieve the objectives of service profit chain (Heskett et al, 2008).

At the service firm level, service design is concerned designing the service system as a configuration of people, processes, competences and technologies (Patricio et al, 2011; Maglio et al, 2009) - akin to enterprise or organization design - to achieve the firm's mission and strategy, a C-level executive-led cross-disciplinary endeavor. Service system design must address the roles of people, technology, shared information (e.g. see Breidbach et al, 2012), as well as the role of customer in co-production processes and the application of competences to benefit others (Gronroos \& Voima, 2013). The design must also address the service systems' requirements for agility and adaptability in alignment with their environments (Spohrer et al, 2006). Consequently, it will influence the design of service delivery system for each service offering conceived as service innovation (Patricio et al, 2011). This design interrelationship will be managed through the modularity principles of the attendant service architecture (step 6).

In sum, service system design, broadly, must address four variables: physical setting; process design - the service blueprinting which designs quality into the service delivery system and the customer value co-creation process of aligning the firm's capabilities to the needs of the customer value constellation (further refinement in step 5); job design - the social technical job design which include addressing the employee motivational requirements; and people - the staff (competence) selection (Goldstein et al, 2002; Patricio et al, 2011). 


\subsection{Customer Experience}

Service design excellence strives to achieve superior customer experience (step 5), which is defined by the usability and pleasurability of the service interactions (Stickdorn \& Schneider, 2010: 84). Service organizations are increasingly managing customer experiences to promote differentiation and customer loyalty. Due to its strategic significance as a competitive differentiator, this specialist practice of service encounter design, whilst an integral part of service system design, is factored out as a crucial step deserving special attention in the overall integrated design method. Customer experience is the outcome of the co-created customer value fulfilled by the service (delivery) system design in line with the CVP of the customer type in question. The desired customer experience envisioned by the CVP for each service type is analyzed as the (outside-in) objectives of service encounter blueprinting design (Bitner et al, 2008; Patricio et al, 2008; Patricio et al, 2011). The service encounter design is a critical element of overall service design, because from the customer's viewpoint "these encounters are the service" (Bitner et al, 2008). The design focuses on maximizing the quality of service experience by the customer, which is contingent on the back-stage information and processes and the front-stage customer handling working seamlessly in unison in satisfying the customer request (Glashko \& Tabas, 2009). This includes aligning the fitness of technology affordances (Zammuto et al, 2007; Leonardi, 2011; Yoo et al, 2012) with customer competencies. Thus, Step 5 is focused on designing for the envisioned customer experience (comprising cognitive, emotional and behavioral factors) over the entire customer journey (Rawson et al, 2013) of service interactions (value co-creation) in line with the service concept (customer value proposition) and strategies (intent and brand value) designed in steps 3 and 1, respectively. Step 5 also seamlessly integrate the customer service experience (activity and context) design (Zomerdijk \& Voss, 2010) with the 
service delivery system design (step 4) to ensure end-to-end service design coherence - mutual alignment of the three contiguous processes of the provider, the service encounter, and the customer (Payne et al, 2008) in satisfying the customer value constellation needs (Patricio et al, 2011).

Customer experience is influenced by the service intensity (the number of actions initiated by the service provider), and the amount of information exchanged in a service encounter (Bitner et al, 2008), all must be designed to ensure lean consumption by the customers (Womack \& Jones, 2005). The service design of multi-interface system must unify service management, human computer interface, and software engineering perspectives into an integrated design embodying the customer experience requirements (Patricio et al, 2008). The design must ensure consistent service experience across all interfaces. It must also account for the dynamic and ongoing engagement process between customers and the service organization, including the emotional, physical, intellectual, or even spiritual perception of the customers (Zomerdijk \& Voss, 2010; Patricio et al, 2011). Customer value is co-created in this dynamic, interactive, non-linear and often unconscious process (Payne et al, 2008; Patricio et al, 2011). Value (in-use) is determined in the context of the performance outcome of the customer's resource integration practice. Thus, the customer experience is culminated from the customer's cognitions, emotions and behavior during the relationship with the supplier, and it determines the use-value (Patricio et al, 2011). The service experience blueprinting method devised by Patricio et al (2008) is adopted for this customer experience design step. 


\subsection{Service Architecture Design}

Service architecture is designed to systematize service design and innovation by providing a common language across different views on service design and a systematic way to operationalize and measure the degree of service architecture modularity (Voss \& Hsuan, 2009). It is designed in accordance with the principle of modularity (Baldwin \& Clark, 1997) comprising five dimensions: components, the interfaces, degree of coupling, and commonality sharing between components, and platform as the overarching configuration of components and interfaces that make up the service architecture (Fixson, 2005; Tiwana et al, 2010; Yoo et al, 2010; Gawer \& Cusumano, 2014). Modularity refers to the degrees by which interfaces between components are standardized (Baldwin \& Clark, 1997) to allow greater component design independence (or loosecoupling), reusability (via composability property) and sharing of common 'platform' component among service families (Tiwana et al, 2010). It provides the basis for mixing and matching of components to meet the mass-customization requirements; yields economies of scale and scope, and can help structure services to facilitate outsourcing. Service architecture practice through the principle of modularity sustains the firm's service ecosystem via 'actor-to-actor' value co-creation (Lusch \& Nambisan, 2015) and enables the focal firm to maintain internal and external fitness and thereby becomes more adaptive to environmental dynamics. Platform strategies are the vehicles for realization of mass customization (Fixson, 2005; Tiwana et al, 2010; Yoo et al, 2010; Gawer \& Cusumano, 2014), generative innovations such as the ecosystem of applications burgeoning on Apple App Store (Yoo et al, 2012), and combinatorial innovations allowing the service module(s) to be easily 'mashed up' (or mix-and-match) with other modules developed by other firms (Yoo et al, 2012). As platform decisions often cut across several service lines or divisional boundaries, platform strategic decisions (including governance and design rules) must belong in the top 
management team who need to and can resolve cross-functional conflicts to jointly-achieve the firm overall strategy.

An important and challenging aspect of service architecture is the interface. Interfaces in services can include people, information, and rules governing the flow of information. Service interface can also include the flow of people. In general, an active role in service customization would be played by both the front-end employees and the customers themselves. This would suggest the service components need to be more loosely coupled than product components (Roth \& Menor, 2003).

A service system can be analyzed, for the purposes of service architecture, in terms of four levels of increasing details in specification: industry level, service company/supply chain level, service bundle level, and service package/component level (Voss \& Hsuan, 2009). At level 0, the industry architectural template delineates the focal firm's position with respect to its network of business ecosystems (Zahra \& Nambisan, 2012) across the value chain and defines the value creation and the division of labor as well as value appropriation and the division of surplus or revenue among the different players (Jacobides et al, 2006). (This is the financial or commercial view of service design that is seen from the Chief Executive Officer/Chief Financial Officer level.) At level 1, the service company and its supply chain(s) are modeled both upstream and downstream, in line with the strategic business logic (Casadesus-Masanell \& Ricart, 2010; Osterwalder \& Pigneur, 2005). Both shared (internal cross-functional) and outsourcing of service components are important consideration for the service company level for economic and resource flexibility reasons, in line with its business strategy. (This is the operations management view of service design that is seen from the Chief Operating Officer level.) At levels 2 and 3, the service concept and service design activities of service innovation practice are harmonized and integrated 
to assure service agility. (This is the Chief Marketing Officer and Chief Information Officer view of detailed service design, operational and management levels.) At level 2, the individual service bundles of the service offering at the company level are analyzed - each bundle is viewed as a set of modules of service delivery, comprising the front- and back-office functions (and associated capabilities). The front-office design must comply with the above-mentioned customer-provider service encounter process design principles to ensure superior customer experience and optimal value creation (step 5 customer experience). At level 3, the service package and component level, the characteristics of the building blocks (components) are specified that contribute to the overall systems architecture, namely: standardization, uniqueness, degree of coupling and replicability (Voss \& Hsuan, 2009). Thus, service architecture enables service agility as new services can be designed and provisioned with minimal cost and little internal change, and the architecture can be dynamically adapted in response to external stimuli. But this would require support by a corresponding modular organizational architecture as well as IS architecture (Voss \& Hsuan, 2009).

Service architecture serves, on one hand, as an end-to-end design governance framework guiding design decision-making in each design process step to ensure, where appropriate, architectural modularity standards compliance to maximize efficient and reusable process design. On the other hand, it also serves as a critical structured knowledge repository in the form of layered architecture of design knowledge base. Service architecture is a 'living' design knowledge base. It complements the knowledge interrelationship map of design process elements (Figure 4). Together they form the knowledge management system for accumulating the continual organizational and customer leaning as part of practicing the integrated design method. Adjustment and modification of any ineffective or obsolete parts of the architecture (knowledge 
repository), based on practitioners' formal field-application (reflection-in-action) feedback on each design process step, is applied via a strict architecture governance process involving all affected stakeholders (business and designer practitioners). This architecture governance process is a crucial part of $i$ SIM which requires practitioners to 'reflect in action' on the effectiveness of each design process element and the consequential impact of the design to its beneficiary. This normative practitioner behavior is a part of developing the firm's dynamic service innovation capabilities (Kim et al, 2015) according to both practice theory and organizational capability theory (see Sections 4.4 above and 5.8 below). It helps minimize path dependency behaviors by practitioners (Teece et al, 1997; Helfat et al, 2007). Such an adaptive design culture requires Clevel leadership leading by example across the multidisciplinary teams.

\subsection{Monetization Design}

Step 7 monetization design is interlinked with customer type design choice in Step 1. Customer types can be chosen (Eisenmann et al, 2006) by the business model as: (a) one-sided - where the end-user customers pay to use the service offered; (b) two-sided - where the end-user customers use the service offered free, which is actually subsidized by the advertiser customers who pay the focal firm to target-advertise to the firm's huge captive audience of end-user customers according to their service usage behaviors - an end-user co-created value offered to the advertisers as a value proposition; or (c) multi-sided - often found in B2B business model context, where different roles played by different actors: service usage by end-users, authorization of service contract by senior executive, and payment for service used by finance officer. Monetization service experience (influenced by monetization intensity) can be further refined and customized by deciding when, what and how money is raised. 


\subsection{Practicing iSIM}

Drawing on the prior design-activity flow patterns and attendant interrelationship map of iSIM model (Section 4.6) and the Patricio et al (2011) multi-level service design method, we illustrate in Figure 6 below how iSIM could be practiced holistically and iteratively top-down from strategy formulation to CVP design to value co-creation via end-to-end service system design, governed by service architecture to ensure the design's internal and external configurational fitness with the environmental dynamics. In Figure 6, the problem space is first set and defined, on the left-hand side, through in-depth market and industry strategic analysis (for strategy design) and customer insights analysis (for CVP, service concept design, etc.) and then solved (i.e. designed) on the right-hand side for each design process step (or element).

\begin{tabular}{|c|c|c|}
\hline & Problem setting & Problem solving \\
\hline $\begin{array}{l}\text { Designing the } \\
\text { strategy }\end{array}$ & $\begin{array}{l}\text { Blue vs red ocean } \\
\text { opportunities }\end{array}$ & $\begin{array}{c}\text { Business logic, brand value } \& \\
\text { platform flexibility }\end{array}$ \\
\hline $\begin{array}{l}\text { Designing the } \\
\text { customer }\end{array}$ & $\begin{array}{l}\text { Customer journey } \\
\text { pain points }\end{array}$ & $\begin{array}{c}\text { Unique customer value } \\
\text { proposition (CVP) } \\
\end{array}$ \\
\hline type \& CVP & & New CVP-aligned configuration \\
\hline $\begin{array}{l}\text { Designing the } \\
\text { service concept }\end{array}$ & $\begin{array}{l}\text { Value Constellation } \\
\text { Experience }\end{array}$ & $\begin{array}{l}\text { congruent with SA modularity } \\
\text { standards } \\
\end{array}$ \\
\hline $\begin{array}{l}\text { Designing the } \\
\text { service system }\end{array}$ & Service experience & $\begin{array}{c}\text { New service system architecture } \\
\text { \& navigation congruent with SA } \\
\text { modularity standards }\end{array}$ \\
\hline $\begin{array}{l}\text { Designing the } \\
\text { service } \\
\text { encounter }\end{array}$ & $\begin{array}{l}\text { Customer } \\
\text { experience }\end{array}$ & $\begin{array}{c}\text { Service experience blueprinting } \\
\text { produces CVP-aligned customer } \\
\text { experience congruent with SA } \\
\text { modularity standards }\end{array}$ \\
\hline $\begin{array}{l}\text { Designing the } \\
\text { monetization }\end{array}$ & $\begin{array}{l}\text { Payment } \\
\text { experience }\end{array}$ & $\begin{array}{c}\text { New payment model } \\
\text { commensurate with CVP }\end{array}$ \\
\hline $\begin{array}{l}\text { Designing internal } \\
\text { \& external fitness } \\
\text { of new service }\end{array}$ & $\begin{array}{c}\text { Service } \\
\text { architecture (SA) }\end{array}$ & $\begin{array}{l}\text { Modularity \& Internal \& external } \\
\text { fitness of new service design }\end{array}$ \\
\hline
\end{tabular}

Figure 6: Practicing $i$ SIM

Design knowledge is transferred between design-process steps as they are being practiced iteratively as illustrated by the interrelationship map (Figure 4 in Section 4.8). For simplicity 
sake, the design process sequence is intentionally not shown in Figure 6 as the sequential path taken is situational, context- and firm-dependent. For instance, the iterative sequential flow from top to bottom of Figure 6 would be typical of a mature organization. On the other hand, a new startup firm may initially not yet have a priority need for service architecture yet during its initial struggle for of business survival trying to make the new service innovation (designed with the other six process elements) aligned with the emerging needs of the target customer type. The need for a strategic decision on the choice of modularity, scalability, reusability and possibly a service platform afforded by the service architecture practice would only become a business priority when the business takes hold and becomes more stabilized. However, if the new startup firm has an ambitious strategy of developing a new service platform from inception, then service architecture will become a central element of the firm's service design process flow. Its design will iterate with strategy.

The central plank of $i \mathrm{SIM}$ is its holistic cross-disciplinary design practice underpinned by the service architecture governance process. The governance process necessary for effectuating the cross-disciplinary holistic integration of design-process steps requires explicit delineation of the roles and responsibilities of cross-disciplinary team members for each and every individual design-process step. The RACI matrices (defined below) provide an effective way to plan, organize and coordinate design activities or processes in a cross-disciplinary team (Cabanillas et al, 2012). It consists of assigning different degrees of responsibility for each design activity/process in the focal firm to the members or roles of an organization. Specifically, Responsible (R) denotes the person or role that must perform the work, be responsible for the activity until the work is finished and approved by an accountable role. Accountable - also Approver or Final Approving Authority - (A) denotes the person or role who must approve the work performed by 
the person responsible for an activity, and who becomes responsible for it after approval. Consulted - sometimes Counsel - (C) denotes this role involves the people whose opinion is sought while performing the work, and with whom there is two way communications. Informed (I) denotes the person or role who is kept up-to-date about the progress of an activity and/or the results of the work, and with whom there is just one-way communication. (Cabanillas et al, 2012: 59). The decision-making governance framework for iSIM could be structured as RACI matrices as illustrated in Table 1. The resultant service system, customer experience and monetization design outcomes will constitute the new service innovation (offering) that will be used by the target customer type. The CVP and service concept together constitute the design requirements for the new service offering, while the service architecture serves as the design governance for the offering's compliance to the modularity, internal and external fitness design constraints.

Table 1: A Sample RACI Governance Framework for the New Integrated Design Method

\begin{tabular}{|c|c|c|c|c|c|c|c|c|}
\hline $\begin{array}{l}\text { Design pro- } \\
\text { cess ele- } \\
\text { ments: }\end{array}$ & $\begin{array}{l}\text { Chief Ex- } \\
\text { ecutive } \\
\text { Officer }\end{array}$ & $\begin{array}{c}\text { Chief } \\
\text { Strategy } \\
\text { Officer }\end{array}$ & $\begin{array}{c}\text { Chief } \\
\text { Marketing } \\
\text { Officer }\end{array}$ & $\begin{array}{c}\text { Marketing } \\
\text { Analyst }\end{array}$ & $\begin{array}{l}\text { Chief Fi- } \\
\text { nancial } \\
\text { Officer }\end{array}$ & $\begin{array}{l}\text { Finance } \\
\text { Analyst }\end{array}$ & $\begin{array}{l}\text { Chief In- } \\
\text { formation } \\
\text { Officer }\end{array}$ & $\begin{array}{c}\text { Information } \\
\text { Systems } \\
\text { Designer }\end{array}$ \\
\hline Strategy & $\mathrm{A}$ & $\mathrm{R}$ & $\mathrm{C}$ & I & $\mathrm{C}$ & I & $\mathrm{C}$ & $\mathrm{C}$ \\
\hline $\begin{array}{c}\text { Customer / } \\
\text { CVP }\end{array}$ & I & $\mathrm{C}$ & $\mathrm{A}$ & $\mathrm{R}$ & I & $\mathrm{C}$ & $\mathrm{C}$ & $\mathrm{C}$ \\
\hline $\begin{array}{c}\text { Service Con- } \\
\text { cept }\end{array}$ & I & $\mathrm{C}$ & A & $\mathrm{R}$ & I & $\mathrm{C}$ & $\mathrm{C}$ & $\mathrm{C}$ \\
\hline $\begin{array}{c}\text { Service Sys- } \\
\text { tem }\end{array}$ & $\mathrm{I}$ & $\mathrm{C}$ & $\mathrm{C}$ & $\mathrm{C}$ & I & $\mathrm{C}$ & A & $\mathrm{R}$ \\
\hline $\begin{array}{l}\text { Customer } \\
\text { Experience }\end{array}$ & I & $\mathrm{C}$ & $\mathrm{C}$ & $\mathrm{C}$ & I & $\mathrm{C}$ & A & $\mathrm{R}$ \\
\hline Monetization & $\mathrm{I}$ & $\mathrm{C}$ & $\mathrm{C}$ & $\mathrm{R}$ & A & $\mathrm{C}$ & $\mathrm{C}$ & $\mathrm{C}$ \\
\hline $\begin{array}{l}\text { Service Ar- } \\
\text { chitecture }\end{array}$ & A & $\mathrm{C}$ & $\mathrm{C}$ & I & $\mathrm{C}$ & I & $\mathrm{R}$ & $\mathrm{C}$ \\
\hline
\end{tabular}

A successful $i \mathrm{SIM}$ practice depends on an effective cross-disciplinary project team organization structure. A different expert role, designated by R and A, would take leadership accountable for each design-process element. But the overall delivery accountability and responsibility of the 
new integrated offering would be the Chief Information Officer and her/his Project Manager, respectively.

The C-level leadership team will be accountable for creating and nurturing the service- and design-thinking (Hastings and Saperstein, 2013) and resulting organizational culture. The organization is characterized by its holistic problem setting and solving capabilities practiced as the

firm's dynamic service capabilities (Kim et al, 2015). Inherent to these organizational capabilities is practice-based knowledge creation (reflection-in-action) processes that underpin the critical tasks of continuous customer and organizational learning and therefore the continuous constitutive refinement of $i$ SIM praxis and the ostensive $i$ SIM practice (Feldman $\&$ Orlikowski 2011).

\section{Exemplar iSIM Practices}

\subsection{Telco Exemplar}

Telecom companies (telcos), like all service organizations, compete on differentiated customer or service experience. The telecom service system consists of a collection of network- and systems-capabilities that together with the resources or capabilities of its partners and suppliers are configured (by service system design) to create a differentiated service offering (Chew, 2010). An exemplar application of $i$ SIM to a telco service innovation process is illustrated below.

In Step 1, telco business executive defines the competitive service strategy and brand value, often founded on customer intimacy value discipline (Treacy and Wiersema, 1995), which is purposefully designed to satisfy the emerging or unmet needs of the (existing and new) customer segments chosen in Step 2. 
In Step 2, telco business executives select customer segments (consumer, corporate, business, wholesale, virtual network operator, etc.) and define the customer value proposition per segment. With the next-generation network technology (Knightson et al, 2005) (see Step 6 - service architecture), telcos may offer a service platform providing software as a service, infrastructure as a service or platform as a service to enable ecosystems of third-party software-based businesses to trade over the service platform.

In Step 3, the product (marketing) manager informed by deep customer insights envisions and defines a new service concept (supported by operations and IT) - e.g. education institutions' emerging need for a virtual classroom service (in support of an innovative remote education service). This new service concept would allow geographically separated students from anywhere (home, office or hotel) to participate in a real-time lecture using any device over any network of their choice while still experiencing the same level of intimate interpersonal interactivity as if they were co-located in the classroom.

In Step 4 service design, IT and network experts will design (supported by marketing and operations) the integrated network and systems solution that satisfies the service concept requirements. Using the service architecture (Step 6) as a reference framework to leverage service component reusability and ensure the solution's fitness with the telco's overall portfolio of services, the IT/network experts may design, on one hand, a quadruple-play service solution, combining broadband, mobile, IPTV and multi-media contents in an integrated service delivery; and, on the other hand, design the appropriate accompanying customer 'service encounter' capability components ensuring end-to-end service integrity in line with the espoused customer service strategy (Step 1) and the attendant customer experience criteria (Step 5). 
In Step 5, customer experience design is typically led by systems designers with human factors engineering expertise (Shaw, 2007). They are skillful in designing service encounter interfaces, particularly in aligning the fitness of technology (Zammuto et al, 2007; Leonardi, 2011; Yoo et al, 2012) with customer competencies. The resulting design satisfies the customer's cognitive, emotive and behavioral requirements across a wide range of usage patterns throughout the end-to-end customer journey (Rawson et al, 2013).

In Step 6, the firm-specific service architecture is used as a reference model for governing the overall aforementioned service design practices. Telco's new service design depends critically on the designer's understanding of the provider's service process and system environment to ensure effective value co-creation and consequentially superior customer experience. The service architecture defines the telco's role and relationships with other stakeholders such as the regulator, competitors, supply-side business (suppliers/partners) ecosystems and customer-side business ecosystems. It is used to design the service (system) solution (Step 4) that provisions the new service concept ideated and selected in Step 3. In pursuit of business model innovation and future new revenue streams, telcos may 'open up' its next-generation service platform (with attendant developer toolkits) to third-party entrepreneurs to develop, sell and transact new API-compatible digital services over the platform, creating a new customer-side digital services ecosystem (Marshall, 2014) and new revenue sources for the telco.

In Step 7, design the innovative m-sided revenue (monetization) model corresponding to each customer type selected in Step 1. For each customer type targeted for each of the new nextgeneration platform service types, an attractive CVP and revenue (monetization) model will be designed to attract and grow the business ecologies around the next-generation telco platform. 


\subsection{Amazon Exemplar}

From initially an online bookstore in early 1990's, Amazon has transformed to become what is today an Open Service Platform (Smedlund, 2012). It offers not only online 'Superstore' retailing service to consumers (shoppers) but also to third-party merchants who sell their products through Amazon online 'Supermall' or who establish their own 'shop fronts' (such as Lacoste) using Amazon web infrastructure technology and managed services. Later, to leverage its unique IT assets and capabilities, the Amazon platform morphed again into an Application Service Provider offering (small) business customers pay-as-you-use SaaS (software as a service) capabilities such as Amazon Web Services and other storage cloud services (Isckia, 2009). Lately, with its Kindle ebook (and later tablet) innovation ${ }^{3}$, Amazon has added yet another platform to its business ecosystem disrupting book publishing and distribution services by connecting the authors directly to the readers - creating possible m-sided markets (Eisenmann et al, 2006). In the following we illustrate the utility of $i$ SIM using Amazon's early incarnations as an online retail store.

Step 1 - Strategy: create a customer-centric online retailing service business that provides online (initially books and later virtually anything) retailing experience that is personalized, convenient, with vast selection, reliable, social and lower prices than those available from the competitors' physical stores.

Step 2 -Customer types: in line with the strategy, select and define the customer value proposition for (initially) basic consumers / online shoppers and (later) merchants selling via Amazon superstore or via own online stores (e.g. Lacoste) using Amazon technology and services - each being serviced via a unique business model but all exploiting Amazon's unique resources and capabilities to amplify the size of value captured by Amazon.

\footnotetext{
${ }^{3}$ This is an example of technology innovation whose conception and development is conversely influenced by the chosen business model (Baden-Fuller and Haefliger, 2013).
} 
Step 3 - Service concept: define the business logic of an online retail bookstore that delivers the value proposition of personalized (powered by Amazon proprietary recommender system), easy-to-use, social (e.g. customers sharing book reviews), convenient, reliable and at a lower cost than the incumbents such as Barnes and Noble.

Step 4 - Service (activity) system design: design the end-to-end order fulfillment, warehouse (procurement and inventory management), logistics (transactional) and distribution activity system (integrating human activities with sophisticated computer graphical user interface, highly scalable web infrastructure, warehouse fulfillment automation systems, and logistics carrier transport systems) to deliver on the aforementioned value proposition.

Step 5 - Customer experience design: design the technology (Zammuto et al, 2007; Leonardi, 2011; Yoo et al, 2012) in terms of functionality (usability, communication, social presence, product presence, and interactivity with back-end) and psychological factors (context familiarity, value-for-money, trust-worthiness) of the front-end graphical user interface (GUI) and associated personalization (recommender) system to create the distinctive Amazon customer value cocreation or customer journey (Shaw, 2007) experience consistent with its brand and strategy (Klaus, 2013). This is assured by designing the end-to-end alignment of the customer (service interaction) process via the front-end GUI (e.g. the Amazon 1-click® shopping), the service encounter process and the back-end fulfillment processes (Payne et al, 2008).

Step 6 - Service architecture design: in line with the strategy and the associated broad service concept, design the Amazon service system as an open service architecture to become the Amazon Open Service Platform (Smedlund, 2012; Isckia, 2009), with clearly specified open service (API) interfaces to allow ‘plug-and-play’ by Amazon's SaaS and/or third party’s service components over the layer (Yoo et al, 2010; Tiwana et al, 2010). Ensure mutual alignment of 
specifications between the service architecture and each new service concept, service design and customer experience design to ensure coherent and consistent service and business model innovation end-to-end.

Step 7 - Monetization design: design the innovative and attractive (value for money) revenue model to match the value proposition of each customer type selected (e.g. merchants using Supermall or enterprises using SaaS) to be served by the Amazon service platform as described in Step 1. Minimize the potential impact of monetization intensity (Casadesus-Masanell and Zhu, 2013) on customer experience. Elucidate and optimize the cost structure of the service design and customer experience design for each customer type to ensure the resultant revenue and cost designs will create the desired profit formula (Johnson et al, 2006) while satisfying the customer value co-creation objective.

\section{$7 \quad$ Practitioners Perspectives}

The proposed $i$ SIM is specifically designed for use by practitioners in their respective businesses and industries. We followed Nenonen \& Storbacka's (2010) method in engaging with selected practitioners (experts) to leverage their practice knowledge to 'co-develop' iSIM. Thirteen experts from ten firms from diverse geographies were selected for a combination of interviews (seven experts) and presentations (to all experts separately) comprising a portfolio of three large enterprises in high technology industries, one medium enterprise in media, five small startups in digital-based business, and one small enterprise in knowledge intensive services. Preliminary interviews were conducted with seven selected practitioners to learn their own real-world experience of service innovation and business model design practices and expectations for the proposed $i \mathrm{SIM}$, and then later get their feedback as to whether the theoretically-founded iSIM 
makes sense and has potential utility for their business. Semi-structured interviews were conducted (around 60 minutes each) on the former followed by one-on-one or group presentation and free-form discussion (60-90 minutes) on the latter. Fourteen interviews plus three group and seven one-on-one presentations to experts were conducted. Overall, the practitioners confirmed iSIM's sensibility and potential utility. We summarize below their perspectives on $i$ SIM.

A common view about service innovation that is best captured by the founding CEO of a successful startup digital-based service business is:

"Service innovation must be simple and exploiting the vacuum!"

The CEO refers to radical service innovation that naturally attracts consumers to the "vacuum". He asserts this refers to anticipating customers' latent needs - those that they cannot yet articulate. While highly supportive of customer co-producing/co-designing service offerings and value cocreation, the CEO cautions against mindlessly aligning to customer needs as this will only deliver incremental rather than radical innovation because customers can only articulate what they know (based on their existing needs or existing problems) but they don't know what they do not yet know so cannot articulate the vacuum. This view echoes somewhat Ordanini \& Parasuraman's (2011) finding that "collaborating with customers fosters innovation volume [exploitation] but not radicalness [exploration]" (p.3). On the other hand, the practitioners stressed the importance of engaging the 'influencers' (the opinion leaders) in the co-production and co-design processes. The practitioners see customers having multiple roles, so their participation role in the service innovation process must be carefully orchestrated to ensure it is fit for purpose. This is consistent with the findings of Moeller et al, (2013) that customers play multiple roles when engaging in collaborative value creation processes. 
The practitioners also expressed a desire for a systematic approach to integrated design of service and business model, a practice which is still under-developed in the real-world, as exemplified by the view of an entrepreneur below:

\footnotetext{
"When we were figuring out a new business or service idea we were also figuring out the potential customer value and ways of making money from it. But we don't really have a systematic and consistent way of doing it yet."
}

It is noteworthy that practitioners invariably conceive of the desirable customer value proposition (CVP) to accompany their new business or service idea even before the idea or service concept is fully developed. One successful entrepreneur stated that:

"To have any legs to run on, a new idea must have clear benefits to the customers."

A common trait of these entrepreneurs is a preference for action as opposed to excessive analysis on their innovative ideas. For instance, they 'toyed' an initial service concept (CVP) simultaneously with its possible monetization options and then:

"quickly customer-trialed to see if the concept has got 'legs' to run or not".

An innovator from a large high technology company we interviewed echoed this approach to CVP and/or service concept development and trialing with customers. Here, the focal firm trialed with a 'lead' target prospectus customer its innovative technology-based service idea that proposed to enhance the customer value constellation's ability to co-create superior value for themselves with the focal firm's innovative service. The practitioner from the large company remarked:

"We helped our prospects analyze their value networks to identify what factors slowed down their businesses and stopped them from growing. From the in-depth analyses we knew we needed a third-party solution partner to define a common platform that would help transform their current business operating models to maximize revenues and reduce costs. Together with 
the selected third-party partner we constructed a new service and business model idea. We trialed the new service and business model idea with a couple of prospects to confirm that the idea was feasible and acceptable to the prospects as a cost-effective model for transforming their business."

But according to a successful startup founding-CEO, the service concept is still largely a hypothesis and must be flexible to "pivot to market needs". His advice to CVP and service concept design below exemplifies the collective experiences of other practitioners:

\footnotetext{
"The service concept must be easy to understand by the target audience. It must have the ability to pivot to market needs. This means the [service concept design] construct must be flexible, replicable and scalable. Its purpose and value proposition to the customers must have a degree of 'sexiness' and its revenue model must not be [seen to be] exploitative."
}

Some entrepreneurs even propositioned to "dare to think big" from inception - conceiving the service concept as a possible platform with a range of possible revenue models (that exploits the vacuum) upon which future communities or business ecosystems may thrive. This is exemplified by another startup CEO’s remark:

\footnotetext{
"In my [digital] business, platform is the new reality. We must think big and imagine how we could grow an ecosystem around our service to make it a platform."
}

A common problem for service innovation, according to the practitioners, is the ability to scale the service concept/design. To that end, they see the iSIM with its service architecture as valuable and practical. This is exemplified by the comment:

\footnotetext{
"I like the end-to-end view. It is how we think at all times. The service architecture idea makes sense. I think it could help me manage end-to-end better and how to scale the business systematically."
} 
With regard to business model design practice, the practitioners opined (as exemplified by the quote below) their current immature practice and the increasing challenge for business leaders of learning to manage the paradox of 'chaos' and 'stability' ambidextrously which is a highly critical dynamic capability (Smith \& Lewis, 2011; O’Reilly \& Tushman, 2011):

"We [the practitioners] often fail to put in place not only internal but also external fitness to our [business model] designs. Business model design must plan sufficiently far ahead to accommodate 'chaos' [of the market] and 'stability' [of the internal processes]."

They noted that the dilemma of chaos being associated to creativity and scalability being associated with stability would pose a similar challenge to managing service architecture practice. We have addressed this challenge in the specification of iSIM to the satisfaction of the practitioners. This is achieved by applying a formal governance process to effect adaptation of the service architecture and the resultant end-to-end design practices in line with the emergent new knowledge triggered by market chaos and accrued from a built-in organization and customer learning practice (e.g. see interrelationship map in Figure 4).

The practitioners view design practices as being actually iterative and holistic, guided by the chief designer's emergent cognitive frame of the interrelationship between the variables of each design step. For instance, following the articulation of a platform-centric service/business strategy and the desired service conceptual model, the chief designer may proceed to design an initial model of the envisioned service (platform) architecture (with the associated initial interface and modularity requirements defined) and the business (revenue) model that would fulfill the strategy and guide the on-going development of the first and future service concept design. This too has been accommodated in the proposed iSIM, as illustrated by how iSIM will be practiced in Section 5.8 . 
All in all the practitioners' expert input and feedback to the proposed iSIM have been invaluable and duly incorporated in the 'co-creation' of the final version presented in this article. But, because the business world is dynamic, iSIM will be subject to further refinement by its large-scale field trials by several selected firms in Europe over the period 2015-17.

\section{Managerial Implications}

Service innovation is a complex endeavor requiring a blend of creativity and discipline. The former is required in exploring radically new ideas to solve 'wicked' customer problems, while the latter to systematically or methodologically convert the idea, by creative design, into innovative services that customers are willing to pay for. Service innovation and business model innovation are the source for business growth. They are closely interrelated and can be effectively designed by means of the proposed iSIM. Practicing iSIM involves an iterative end-to-end coherent flow of the seven holistic design-process elements. The sequential flow of these designprocess elements is adaptive to suit the practicing firm's maturity, context and situation. There are several managerial implications in order to gain practice mastery of the new integrated design method.

First, because service innovation with iSIM is a multi-disciplinary team effort, adoption of iSIM practice must be committed by the C-level leadership team. This means the C-level leadership should create an organization structure that promotes flexible and ease of formation of multi-disciplinary innovation project teams. This entails a management practice that incentivizes cross-disciplinary collaboration by adopting a governance framework such as the RACI matrices; a culture of service- and design-thinking that promotes 'outside-in', customer-centric, holistic, architectural designing; and a human resource architecture that nurtures both efficiency 
(scalability) and flexibility (innovative) cognitive capabilities. It also rewards continuous customer and organizational learning to adapt iSIM practice to maintain evolutionary fitness with the changing markets. To ensure successful adoption of iSIM, a formal change management program should be instituted by the CEO. A responsible program manager should be appointed together with and an accountable officer from the C-executive suite, such as CMO or CIO. Success will be measured in the short term by the efficacy of iSIM in designing new service innovation and, in the long term, the focal organization's enhanced service innovation capabilities such as those identified in Kim et al (2015) and den Hertog et al (2010). The program team should be formed from the existing or equivalent NSD organization to ensure the change is headcountcost neutral when compared with the existing in-house method while maximizing the organization's absorptive capacity for the proposed iSIM. A new service innovation project should be first trialed to obtain an initial end-to-end organizational learning of utilizing iSIM. The usual change management protocols should be followed where implementation problems should be surfaced quickly and rectified immediately and post-implementation review should be conducted to assess iSIM's efficacy and any further improvements required. The iSIM (probably refined based on organizational learning) should be rolled out gradually on a project-by-project basis as determined by the C-level NSD governance process as and when its efficacy for the firm is confirmed. In this way, organizational change introduced by $i$ SIM will be evolutionary and any additional costs incurred will be principally on iSIM training and workshop to facilitate the NSD designers' absorption of the new practice.

Second, as noted and favored by the practitioners, iSIM should be practiced iteratively and holistically as an agile approach to commercializing service innovation. Managers should be tolerant of experimentation (and therefore failure) and create a governance framework for and 
culture of organizational and customer learning to quickly align the new service to customer needs. This means creating an innovation project infrastructure that facilitates designing and monitoring usage of the new service, and capturing the new design knowledge accrued from the iterative steps of practicing, learning, and updating iSIM in line with the cycle of "practicepractitioner-praxis' and as illustrated by the interrelationship map in Figure 4.

Third, to ensure end-to-end design consistency, integrity and ease of adaptation with changing environment, and to be able to make sound strategy-aligned design decisions in each design step, the lead designer should practice open leadership to encourage new ideas from within and outside the innovation team, and possess collaborative and absorptive capabilities to integrate multidisciplinary knowledge so as exploit these ideas to commercial ends. Over time, practices of iSIM's seven design-process elements together cumulatively constitute the organization's innovative and dynamic capabilities which will assure the firm's competitiveness and sustainability.

\section{Conclusions and Future Work}

Service innovation is focused on creating customer value. To capture value for the innovator, service innovation must be commercialized using an attractive business model. In response to the research question, this article has developed a theoretically-founded new integrated design method, known as iSIM (integrated Service Innovation Method) for designing a new service and business model concurrently. iSIM's sensibility and potential utility has been evaluated by selected practitioners and its efficacy by two exemplar case studies using secondary data.

The theoretical strength of iSIM is in its unification of disparate theoretical constructs from diverse disciplines to ensure internal and external fitness and end-to-end consistency of 
integrated design. Its practical strength lies with its holistic and cross-disciplinary nature with 'reflection-in-action' in each design step to ensure customer and organizational learning. This allows disparate experts from business, operations and IT to collaboratively apply iSIM to solve customer problems situationally and contextually as well as iteratively and holistically. Each expert will learn and improve iSIM constitutively from each application step (praxis). Consequently, the seven $i \mathrm{SIM}$ design steps may be sequenced differently contingent on the problem context. Continual learning via reflection-in-action of each design step will help make iSIM a dynamic capability as theorized in Kim et al (2015). This is due to $i$ SIM's capacity to align the firm with its dynamic external market environment. Further, agile $i$ SIM practice would entail rapid business model experimentation of any new service concept to test its commercial viability before committing capital on the comprehensive detailed design process. It also reflects on the managerial implications of and capabilities required for practicing $i$ SIM.

Notwithstanding the above contributions, a limitation remains with $i$ SIM's lack of empirical validation. This limitation will be alleviated by a recently funded three-year research program (2015-17) that will conduct field-trial of $i$ SIM with selected partnering companies in Europe. This future research will entail adaptation of $i$ SIM to fit with each partner firm's idiosyncratic business needs. It will investigate and develop theories for the empirical relationships and microfoundations of the co-evolution of $i \mathrm{SIM}$, its practice (praxis) and the resultant dynamic service innovation capabilities that $i$ SIM practice produces for the partnering firms.

Another limitation of the article is iSIM's lack of formal specification. Formal techniques such as e3Value (Gordijn \& Akkermans, 2003; Gordijn et al, 2012) and DEMO (Pombinho, Tribolet \& Aveiro, 2014) previously used to model value flow of business model and service system could be candidate methods for trial formal specification of an ontological model of $i$ SIM.. A formal 
ontological model of iSIM would enable an iSIM software tool to be designed and developed in the future. The $i$ SIM software tool is envisioned to aid service and business model designers and innovation stakeholders in systematic and automated management of iSIM's complex web of design activities and their causality. We hope this article would inspire service/business model designers and software engineers to collaborate in the future to research into the design and construction of such an iSIM software tool.

\section{References}

Achtenhagen, L., Melin, L. \& Naldi, L. (2013). Dynamics of business models - strategizing, critical capabilities and activities for sustained value creation. Long Range Planning 46, 427-442.

Adner R. \& Kapoor. R. (2010). Value creation in innovation ecosystems: how the structure of technological interdependence affects firm performance in new technology generations. Strategic Management Journal 31(3), 306-333,

Agarwal R. \& Selen. W. (2011). An Integrated View of Service Innovation. In Demirkan, H., Spohrer, J. C. and Krishna, V. [Eds.], Service systems implementation, Service Science: Research and Innovations in the Service Economy, 253-274. Springer, New York

Alam, I. (2006). Removing the fuzziness from the fuzzy-end of service innovations through customer interactions, Industrial Marketing Management, 35(4), 468-80.

Amit, R. \& Zott, C. (2012). Creating value through business model innovation. MIT Sloan Management Review, 53(3), 41-49.

Anderson, J. C. Narus J. A. \& van Rossum, W. (2006). Customer Value Propositions in Business Markets, Harvard Business Review, 84(3), 91-99 
Arend. R. J. (2013). The business model: present and future - beyond a skeumorph. Strategic Organization, 11(4), 390-402.

Arnould, E. J. (2008). Service-dominant logic and resource theory, Journal of the Academy of Marketing Science, 36, 21-24

Aspara, J., Hietanen, J. \& Tikkanen, H. (2010). Business model innovation vs replication: financial performance implications of strategic emphases. Journal of Strategic Marketing, 18(1), 39-56.

Baden-Fuller C. and Haefliger. S. (2013). "Business models and technological innovation,” Long Range Planning, 46, 419-426.

Baldwin, C. Y., \& Clark, K. B. (1997). Managing in an age of modularity. Harvard Business Review, 75(5), 84-93.

Bettencourt, L. A. (2010). "Service innovation: how to go from customer needs to breakthrough services," McGraw-Hill, New York,

Bitner, M. J. Ostrom, A. J. \& Morgan, F. N. (2008). "Service blueprinting: a practical technique for service innovation," California Management Review, 50(3) , 66-94

Bock, A. J., T. Opsahl, G. George \& D. M. Gann (2012). “The effects of culture and structure on strategic flexibility during business model innovation," Journal of Management Studies, 49(2), 279-305

Breidbach, C. F., Kolb, D. G. \& Srinivasan, A. (2012). Connectivity in service systems: does technology-enablement impact the ability of a service system to co-create value? Journal of Service Research 16(3), 428-441.

Cao, L. (2014). Business Model Transformation in Moving to a Cross-Channel Retail Strategy: A Case Study, International Journal of Electronic Commerce, 18 (4), 69-95. 
Cabanillas, C., Resinas, M. \& Ruiz-Cort'es, A. (2012). Automated Resource Assignment in BPMN Models Using RACI Matrices. In R. Meersman et al. (Eds.): On the Move to Meaningful Internet Systems: OTM 2012 Part I, LNCS 7565, pp. 56-73, 2012, SpringerVerlag Berlin Heidelberg.

Casadesus-Masanell R. \& Ricart, J. E. (2010). From strategy to business models and onto tactics, Long Range Planning, 43, 195-215,

Casadesus-Masanell R. \& Zhu. F. (2013). Business model innovation and competitive imitation: The case of sponsor-based business models. Strategic Management Journal, 34, 464-482,.

Chandler, J. D. \& Lusch, R. F. (2014). Service systems: a broadened framework and research agenda on value propositions, engagement, and service experience, Journal of Service Research, 1-17

Chen, J-S, Tsou, H. T. \& Huang, A. Y-H. (2009). Service Delivery Innovation: Antecedents and Impact on Firm Performance. Journal of Service Research, August 2009; 12(1), 36-55

Chesbrough, H. (2010). Business Model Innovation: Opportunities and Barriers, Long Range Planning 43,354-363,

Chesbrough H. \& Davies, A. (2010). “Advancing service innovations," in P. P Maglio, Kieliszewski and J. C. Spohrer (Eds.), Handbook of Service Science, Springer New York, $579-601$

Chew, E. K. (2010). Service Science: A Reflection from Telecommunications Service Perspective. In Maglio P., Kieliszewski C., Spohrer J. (eds), Handbook of Service Science, Springer, New York, 359-386,

Chew, E. K. (2013). An integrative design framework for new service development. Proceedinsg of the Australasian Symposium of Service Research and Innovation, Sydney, Australia, Nov 
Chew. E. K. (2014a). Service innovation for the digital world, Journal of Enterprise Modelling and Information Systems Architecture. In press.

Chew. E. K. (2014b). Linking a service innovation-based framework to business model design. Proceedings of IEEE Conference on Business Informatics, Geneva, Switzerland, July.

Clark, G. Johnston R. \& Shulver, M. (2000). Exploiting the service concept for service design and development, in J. Fitzsimmons and M. Fitzsimmons, (Eds.), New Service Design. Sage, Thousand Oaks, CA, 71-91.

Collis, D. G. (1994). Research Note: How valuable are organizational capabilities? Strategic Management Journal, 15, 143-152.

Crossan, M. M \& Apaydin, M. (2010). A multi-dimensional framework of organizational innovation: a systemmatic review of the literature. Journal of Management Studies, 47(6), $1154-1191$.

Demil B. \& Lecocq. X. (2010). Business model evolution: in search of dynamic consistency. Long Range Planning 43, 227-246,

Demirkan, H., Spohrer, J. C. \& Krishna, V. [Eds.] (2011). Science of service systems, Service Science: Research and Innovations in the Service Economy. Springer, Boston

Demirkan, H. Spohrer J. C. \& Krishna V. [Eds.], (2011). Service systems implementation, Service Science: Research and Innovations in the Service Economy. Springer, New York

den Hertog, P. (2002), Co-producers of innovation: on the role of knowledge-intensive business services in innovation, in Gadrey, J. and Gallouj, F. Eds. (2002), Productivity, Innovation and Knowledge in Services: New Economics and Socio-Economic Approaches, Edward Elgar, Cheltenham, UK. 223-255. 
den Hertog, P., van der Aa, W. \& de Jong, M. W. (2010). Capabilities for managing service innovation: towards a conceptual framework, Journal of Service Management, 21 (4), 490514.

de Jong, J.P.J. \& Vermeulen, P.A.M. (2003), Organizing successful new service development: a literature review, Management Decision, 41 (9), 844-58.

Dorner, N., Gassmann, O. and Gebauer, H. (2011). Service innovation: why is it so difficult to accomplish? Journal of Business Strategy, 32 (3), 37-46

Dougherty, D. (2004). Organizing practices in services: capturing practice-based knowledge for innovation, Strategic Organization 2(1), 35-64.

Doughery, D. \& Dunne, D. D. (2011). Organizing ecologies of complex innovation. Organization Science 22(5), 1214-1223.

Doz, Y. L. \& Kosonen, M. (2010). Embedding strategic agility: A leadership agenda for accelerating business model renewal. Long Range Planning 43,370-382.

Edvardsson, B. Gustafsson, A. \& Enquist, B. (2007). Success factors in new service development and value creation through services, in D. Spath and K-P. Fahnrich (Eds), Advances in Services Innovations, 166-183.

Edvardsson, B. Gustafsson A. \& Roos, J.. (2005), Service portraits in service research: a critical review, International Journal of Service Industry Management, 16(1), 107-121.

Edvardsson B. \& Olsson, J. (1996). Key concepts for new service development, Service Industries Journal, 16(2), 140-164.

Edvardsson, B., Tronvoll, B., \& Gruber, T. (2011). Expanding understanding of service exchange and value co-creation: a social construction approach. Journal of the Academy of Marketing Science, 39(2), 327-339. 
Eisenhardt, K.(1989). Building theories from case study research. Academy of Management Review, 14, 532.

Eisenhardt, K., Graebner, M. (2007). Theory building from cases: opportunities and challenges. Academy of Management Review 50, 25-32.

Eisenmann, T., Parker, G. \& Van Alstyne, M. W. (2006). Strategies for 2-sided markets. Harvard Business Review, 84(10), 92-101

Engel, J. F., Thompson, A. M., Nunes P. F. \& Linder, J. C. (2006). Innovation unbound. Accenture Publication, Outlook 1, 28-37.

Feldman, M. S. (2000). Organizational routines as a source of continuous change. Organization Science. 11(6), 611-629.

Feldman, M. S. \& Orlikowski, W. J. (2011). Theorizing practice and practicing theory. Organization Science 22(5),1240-1253.

Fitzgerald, M, Kruschwitz, N., Bonnet, D. and Welch, M. (2014). Embracing Digital Technology: A New Strategic Imperative MIT Sloan Management Review 55(2), 1-12.

Fitzsimmons J. A. \& Fitzsimmons, M. J. (2007). Service management: Operations, Strategy, Information Technology. Sixth edition, McGraw-Hill Irwin, New York, NY.

Fitzsimmons J. A. \& Fitzsimmons, M. J. (2010). Service Management: Operations, Strategy, Information Technology. Seventh edition, McGraw-Hill Irwin, New York, NY,

Fixson, S. K. (2005). Product architecture assessment: a tool to link product, process, and supply chain design decisions, Journal of Operations Management, 23 (3/4), 345-369,

Froehle C. M. \& Roth, A. (2004). New measurement scales for evaluating perceptions of the technology-mediated customer service experience, Journal of Operations Management 22(1), 1-22, 
Fynes B. \& Lally, A. M. (2008) Innovation in services: from service concepts to service experiences, in B. Hefley and W. Murphy (Eds.), Service Science, Management and Engineering Education for the $21^{\text {st }}$ Century, Springer, 229-333

Gadrey J.\& Gallouj F. (2002), Productivity, Innovation and Knowledge in Services: New Economic and Socio-economic Approaches. Edward Elgar Publishing, Cheltenham, UK,

Gallouj, F. (2002). Innovation in the service economy: the new wealth of nations, Cheltenham, UK: Edward Elgar.

Gallouj, F. \& Weinstein, O. (1997). Innovation in services. Research Policy, 26, 537-556.

Galvagno, M. \& Dalli, D. (2014), Theory of value co-creation: a systematic literature review, Managing Service Quality, Vol. 24 Iss 6 pp. 643 - 683

Gawer, A. \& Cusumano, M. A. (2014). Industry platforms and ecosystem innovation, Journal of Product Innovation Management, 31(3): 417-433

George, G. \& Bock, A. J. (2011). The business model in practice and its implications for entrepreneurship research. Entrepreneurship Theory and Practice, 35 (1), 83-111.

Glushko R. J. \& Tabas, L. (2009). Designing service systems by bridging the "front stage" and “back stage”, Information Systems, E-business Management, 7, 407-427.

Goldstein, S. M. Johnston, R. Duffy J. \& Rao, J. (2002). The service concept: the missing link in service design research? Journal of Operations Management 20(2), 121-134

Gordijn, J. \& Akkermans, H. (2003). Value based requirements engineering: Exploring innovative e-commerce idea. Requirements Engineering Journal 8(2), 114-134.

Gordijn, J., Razo-Zapata, I., De Leenheer, P. \& Roel Wieringa (2012). Challenges in Service Value Network Composition. In K. Sandkuhl, U. Seigerroth, and J. Stirna [Eds.]. 
Proceedings of Enterprise Modeling, Lecture Notes in Business Information Processing 134, pp. $91-100,2012$

Gregor, S. \& Hevner, A. R. (2013). Positioning and presenting design science research for maximum impact, MIS Quarterly, 37(2), 337-355

Grönroos C. \& Voima, P. (2013). Critical service logic: making sense of value creation and cocreation, Journal of the Academy of Marketing Science, 41:133-150

Hastings, H. \& Saperstein, J. (2013). A practice-driven service framework for value creation, Proceedings of IEEE International Conference on Business Informatics, Piscataway, NJ, USA

Hefley B. \& Murphy W. (Eds.), (2008). Service Science, Management and Engineering Education for the $21^{\text {st }}$ Century, Springer, 341-345

Heinonen, K., Strandvik, T., Mickelsson, K.-J., Edvardsson, B., Sundström, E., \& Andersson, P. (2010). A customer-dominant logic of service, Journal of Service Management, 21(4), 531548.

Helfat, C. Finkelstein, S. Mitchell, W. Peteraf, Singh, M. H., Teece D. \& Winter. S. (2007). Dynamic capabilities: understanding strategic change in organizations, Blackwell, Oxford,.

Helkkula, A., Kelleher, C., \& Pihlström, M. (2012). Characterizing value as an experience: implications for service researchers and managers, Journal of Service Research, 15(1), 5975.

Heskett, J. L. Jones, T. O. Loveman, G. W. Sasser W. E. \& Schlesinger, L. A. (2008). Putting the service-profit chain to work, Harvard Business Review, 86(7/8), 118-129.

Hevner, M. T. March, J. \& Park. (2004). Design Science in Information Systems Research, MIS Quarterly, 28(1), 75-105,. 
Hienerth, C., Keinz, P. \& Lettl, C. (2011). Exploring the nature and implementation process of user-centric business model. Long Range Planning, 44, 344-374.

Holmlid S. \& Evenson, S. (2008). Bringing service design to service sciences, management and engineering, in B. Hefley and W. Murphy (Eds.), Service Science, Management and Engineering Education for the $21^{\text {st }}$ Century, Springer, 341-345

Iansiti, M., \& Levien, R. (2004). Strategy as ecology. Harvard Business Review, 82(3), 68-78.

Isckia, T. (2009). Amazon's Evolving Ecosystem: A Cyber-bookstore and Application Service Provider, Canadian Journal of Administrative Sciences 26, 332-343,

Jacobides, M. G., Knudsen, T, \& Augier, M. (2006). Benefiting from innovation: Value creation, value appropriation and the role of industry architectures. Research Policy 35, 1200-1221.

Jacobides, M. G. \& Winter, S. G. (2012) Capabilities: Structure, Agency, and Evolution. Organization Science, 23(5), 1365-1381

Johannessen J. A. \& Olsen, B. (2010). The future of value creation and innovations: aspects of a theory of value creation and innovation in a global knowledge economy, International Journal of Information Management 30, 502-511

Johnson, M. W. Christensen M. C. \& Kagermann. H. (2008). Reinventing your business model. Harvard Business Review 86 (12), 50-59,.

Kaplan R.S. \& Norton, D.P. (2004). Strategy Maps. Boston, MA: Harvard Business School Press,

Karpen, I. O., Bove, L. L., \& Lukas, B. A. (2012). Linking service dominant logic and strategic business practice: a conceptual model of a service-dominant orientation. Journal of Service Research, 15(1), 21-38. 
Klaus, P. (2013). The case of Amazon.com: towards a conceptual framework of online customer service experience (OCSE) using the emerging consensus technique (ECT). Journal of Services Marketing, 27(6), 443-457.

Kim, M., Song, J. \& Triche, J. (2015). Towards an integrated framework for innovation in service: A resource-based view and dynamic capabilities approach. Information Systems Frontiers, 17(3), 533-546.

Kindstro“m, D. (2009), Creating Business out of Industrial Offerings, MTC, Stockholm.

Knightson, K., Morita, N, \& Towle, T. (2005), NGN Architecture: Generic Principles, Functional Architecture, and Implementation, IEEE Communications Magazine, October, 49-56.

Korkman, O., Storbacka, K., \& Harald, B. (2010). Practices as markets: value co-creation in einvoicing. Australasian Marketing Journal, 18(4), 236-247.

Kowalkowski, C. (2011). Dynamics of value propositions: insights from service-dominant logic. European Journal of Marketing, 45(1/2), 277-294.

Lanning, M. \& Michaels, E. (1988). A Business is a Value Delivery System, McKinsey Staff Paper No. 41, July

Leonardi, P. M. (2011). When flexible routines meet flexible technologies: affordance, constraint, and the imbrications of human and material agencies. MIS Quarterly, 35(1), 147-167.

Li, C. (2010). Open Leadership: how social technology can transform the way you lead, JosseyBass: Hoboken, NJ, USA.

Lusch, R. F. \& Nambisan, S. (2015). Service innovation: a service dominant logic perspective, MIS Quarterly, 39(1), 155-175.

Lusch, R. F. Vargo S. L. \& O’Brien, M. (2007) Competing through service: insights from service dominant logic, Journal of Retailing, 83, 5-18. 
MacDuffie, J. P. (2013). Modularity-as-property, modularity-as-process, and 'modularity'-asframe: lessons from product architecture initiatives in the global automotive industry, Global Strategy Journal, 3: 8-40 (2013)

Maglio P. P. \& Spohrer, J. (2008) Fundamental of service science, Journal of the Academy of Marketing Science, 36, 18 - 20,

Maglio, P. P. Srinivasan, S. Kreulen J. T. \& Spohrer, J. (2006). Service systems, service scientists, SSME and innovation, Communications of the ACM, 49(7), 81-85

Maglio, P. P. Vargo, S. L. Caswell N. \& Spohrer, J. (2009). The service system is the basic abstraction of service science, Information Systems E-Business Management, Springer Online Publication,

Marshall, P. (2014). How APIs accelerate digital services. In: Perspectives 2014, TM Forum. http://perspectives_tmforum.org/how-apis-accelerate-digital-services/ (accessed 15 April 2014).

McGrath. R. G. (2010). Business models: a discovery driven approach. Long Range Planning, $43,247-261$.

Meyer, M. H., \& DeTore, A. (2001). Perspective: Creating a platform-based approach for developing new services,.Journal of Product Innovation Management, 18(3), 188-204.

Mickelsson, K-J. (2013). Customer activity in service, Journal of Service Management 24 (5), pp. $534-552$

Moeller, S., Ciuchita, R., Mahr, D., Odekerken-Schroder \& Fassnacht, M. (2013). Uncovering collaborative value creation patterns and establishing corresponding customer roles, Journal of Service Research, 16(4), 471-487. 
Nenonen, S. and Storbacka, K. (2010). Business model design: conceptualizing networked value co-creation. International Journal of Quality and Service Sciences, 2(1), 43-59.

Normann R. \& Ramirez, R. (1993). From value chain to value constellation: designing interactive strategy, Harvard Business Review, 71(7/8), 65-77.

Ordanini, A. \& Parasuraman, A. (2011). Service innovation viewed through a service-dominant logic lens: a conceptual framework and empirical analysis. Journal of Service Research, 14(1), 3-23.

O’Reilly, C. A. \& Tushman, M. L. (2011). Organizational Ambidexterity in Action: How Managers Explore and Exploit, California Management Review, 53 (4), Summer, 5-22.

Ostrom, A., Bitner, M.J., Brown, S., Burkhard, K., Goul, M., Smith-Daniels, V., Demirkan, H. \& Rabinovich, E. (2010). Moving forward and making a difference: research priorities for the science of service, Journal of Service Research, 13 (4), 4-36.

Osterwalder, A. \& Pigneur, Y. (2005). Clarifying business models: origins, present, and future of the concept Communications of the Association for Information Systems, 16, 1-25.

Osterwalder, A., \& Pigneur, Y. (2010). Business model generation: A handbook for visionaries, game changers, and challengers. Hoboken, NJ: Wiley.

Osterwalder, A., \& Pigneur, Y. (2013). Designing Business Models and Similar Strategic Objects: The Contribution of IS, Journal of the Association of Information Systems, 14, Special Issue, 237-244.

Patricio, L. Fisk R. P. \& Cunba, J. F. (2008). Designing multi-interface service experiences: the service experience blueprint, Journal of Service Research, 12(5), 318-334.

Payne, A. \& Frow, P. (2014). Developing superior value propositions: a strategic marketing imperative, Journal of Service Management, Vol. 25 (2), 213-227. 
Payne, F. Storbacka K. \& Frow, P. (2008). Managing the co-creation of value, Journal of the Academy of Marketing Science, 36, 83-96.

Pombinho, J., Tribolet, J. \& David Aveiro, D. (2014). Linking Value Chains - Combining e3Value and DEMO for specifying Value Networks. In Aveiro, D., Tribolet, J. \& Gouveia, D. [Eds.]. Advances in Enterprise Engineering VIII. Lecture Notes in Business Information Processing, 174: 105-119. Proceedings of 4th Enterprise Engineering Working Conference, EEWC 2014, Funchal, Madeira Island, Portugal, May 5-8, 2014.

Prahalad A. K. \& Ramaswamy, V. (2000). Co-opting customer competence, Harvard Business Review, 78(1), $79-87$

Priem, R. L. Butler, J. E. \& Li. S. (2013). Toward reimagining strategy research: restrospection and prospection on the 2011 AMR decade award article, Academy of Management Review, 38(4), 471-489.

Ranjan, K. R. \& Read, S. (2014). Value co-creation: concept and measurement, Journal of the Academy of Marking Science, Published online 5 Aug 2014.

Rawson, E. Duncan \& C. Jones. (2013). The truth about customer experience. Harvard Business Review, 91 (9), 91-98

Rintamäki, T., Kuusela, H. \& Mitronen, L. (2007). Identifying competitive customer value propositions in retailing, Managing Service Quality: An International Journal, 17 (6), 621634.

Ross, J. W., Weill, P. \& Robertson, D. C. (2006). Enterprise Architecture as Strategy, Harvard Business School Press, Boston.

Roth V. \& Menor, L. J. (2003) Insights into service operations management: a research agenda, Production and Operations Management, 12( 2), 145-164. 
Rubalcaba, L.,Michel, S., Sundbo, J., Brown, S.W. \& Reynoso, J. (2012). Shaping, organizing, and rethinking service innovation: a multidimensional framework. Journal of Service Management, 23(5), 696-715.

Sawhney, M. S. (1998). Leveraged high-variety strategies: From portfolio thinking to platform thinking. Journal of the Academy of Marketing Science, 26(1), 54-61.

Shaw, C. (2007). The DNA of Customer Experience: How Emotions Drive Value. Palgrave Macmillan,

Skålén, P., Gummerus, J., von Koskull, C. \& Magnusson, P. R. (2014). Exploring value propositions and service innovation: a service-dominant logic study, Journal of the Academy of Marketing Science, published online Feb 2014.

Siggelkow, N. (2002). Evolution toward fit, Administrative Science Quarterly, 47: 125-59.

Stickdorn M. \& Schneider J. (2010), This is Service Design Thinking. BIS Publishers, The Netherlands,

Schneider, B. \& Bowen, D. E. (2010). "Winning the service game," in P. P Maglio, Kieliszewski and J. C. Spohrer (Eds.), Handbook of Service Science, Springer New York, 31-59

Smedlund, S. (2012). Value cocreation in service platform business models, Service Science, 4(1), 79-88.

Smith, W. K. \& Lewis, M. W. (2011). Toward a theory of paradox: a dynamic equilibrium model of organizing. Academy of Management Review, 36(2), 381-403.

Solaimani, S., Bouwman, H. \& Itälä, T. (2013). Networked enterprise business model alignment: A case study on smart living, Information Systems Frontiers, DOI 10.1007/s10796-0139474-1, 1-17. 
Spohrer, J., Maglio, P. P., Bailey J. \& Gruhl, D. (2007). Steps toward a science of service systems," IEEE Computer, 71-77.

Tan, Y-H. Hofman, W. Gordijn J. \& Hulstijn, J. A. (2011). Framework for the Design of Service Systems. In Demirkan, H., Spohrer, J. C. and Krishna, V. [Eds.], Service systems implementation, Service Science: Research and Innovations in the Service Economy, 51-74. Springer, New York

Teece, J. (2007). Explicating dynamic capabilities: the nature and microfoundations of (sustainable) enterprise performance, Strategic Management Journal, 28, 1319-1350

Teece, J. (2010). Business Models, Business Strategy and Innovation, Long Range Planning 43, 172-194,

Thomas, L. D. W., Autio, E. \& Gann, D. M. (2014). Architectural leverage: putting platforms in context, The Academy of Management Perspectives, 28 (2), 198-219

Thomke, S. (2003). R\&D comes to services - Bank of America's pathbreaking experiments. Harvard Business Review, 81(4), 71-79.

Tiwana, A., Konsynski, B. \& Bush, A, A. (2010). Platform evolution: Coevolution of platform architecture, governance, and environmental dynamics. Information Systems Research 21(4), $675-687$.

TMF (2004). Enhanced Telecom Operations Map (eTOM): The Business Process Framework, GB921, TeleManagement Forum Approved Version 4.0, March

Treacy M. \& Wiersema, F. (1995). The Discipline of Market Leaders. Cambridge, Mass. Perseus Books,

Tung, W-F., Yuan, S-T., Wu, Y-C. \& Hung, P. (2014). Collaborative service system design for music content creation. Information Systems Frontiers, 16 (2), 291-302. 
Vargo S. L. \& Lusch, R. F. (2004). Evolving to a new dominant logic for marketing, Journal of Marketing, 69, 1-17.

Vargo S. L. \&Lusch, R. F. (2008) Service-dominant logic: continuing the evolution, Journal of the Academy of Marketing Science, 36, 1-10

Vargo, S. L. Maglio P. P. \& Akaka, M. A. (2008). On value and value co-creation: a service systems and service logic perspective, European Management Journal 26, 145-152

Von Hippel, (2001) "Perspective: user toolkits for innovation," The Journal of Product Innovation Management, 18, 247-257

Voss C. A. \& Hsuan, J. (2009). Service architecture and modularity, Decision Sciences, 40(3), $541-569$

Voss C. \& Hsuan, J. (2011). Service Science: The Opportunity to Re-think What We Know about Service Design. Demirkan, H., Spohrer, J. C. and Krishna, V. [Eds.], Science of service systems, Service Science: Research and Innovations in the Service Economy, 231-244. Springer, Boston (2011)

Whittington, R. (2006). Completing the Practice Turn in Strategy Research, Organization Studies, 27(5), 613-634.

Womack, J. P. \& Jones, D. T. (2005). Lean consumption, Harvard Business Review, 9, 58-68,

Xue, M. \& Harker, P. T. (2002). Customer efficiency: Concept and its impact on e-business management, Journal of Service Research, 4(2), 253-267 (2002)

Yoo, Y., Boland, R. J., Lyytinen, K. \& Majchrzak, A. (2012). Organizing for innovation in the digital world. Organization Science, 23(5), 1398-1408.

Yoo, Y., Henfridsson, O. \& Lyytinen, K. (2010). The new organizing logic of digital innovation: the agenda for information systems research. Information Systems Research 21(4), 724-735. 
Yin, R. (2007). Case Study Research: Design and Methods. SAGE Publications Ltd, Thousand Oaks.

Zadeh, H. S., Lowe, D. \& Gavanovich, I. (2014). A Scalable Services Framework for Modeling Service Exchange Networks, Hawaii International Conference on System Sciences (HICSS), Jan. 6-9, 2014, pp: 2978-2983, ISBN: 978-1-4799-2504-9, Waikoloa, HI, USA.

Zahra, S. A. \& George, G. (2002), Absorptive capacity: a review, reconceptualization, and extension, Academy of Management Review 27 (2), 185-203

Zahra, S. A. \& Nambisan, S. (2012). Entrepreneurship and strategic thinking in business ecosystems. Business Horizons, 55, 219-229.

Zammuto, R. F., Griffith, T. L., Majchrzak, A., Dougherty, D. J. \& Faraj, S. (2007). Information technology and the changing fabric of organization. Organization Science, 18(5), 749-762.

Zomerdijk, L. G. \& Voss, C. A. (2010). Service design for experience-centric services. Journal of Service Research 13(1), 67-82.

Zott, C. \& Amit, R. (2010). Business model design: an activity system perspective. Long Range Planning, 43, 216-226,

Zott, C. \& Amit, R. (2013). The business model: A theoretically anchored robust construct for strategic analysis, Strategic Organization, 11(4), 403-411. 